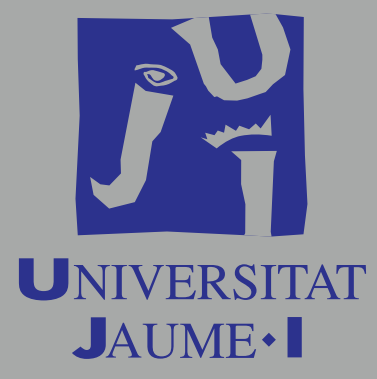

\title{
Química Analítica i Salut Pública
}

Félix Javier Hernández Hernández

\section{Lliçó inaugural del curs 2013/14}




\section{LLIÇÓ INAUGURAL DEL CURS 2013-2014}

\section{QUÍMICA ANALÍTICA I SALUT PÚBLICA}

Félix Javier Hernández Hernández

Catedràtic de Química Analítica

Director del Laboratori d'Anàlisis de Residus de Plaguicides (LARP) i de I'Institut Universitari de Plaguicides i Aigües (IUPA)

Castelló de la Plana, setembre de 2013 
Edita: Servei de Comunicació i Publicacions

Universitat Jaume I

Edifici Rectorat i serveis centrals

Campus del Riu Sec

12071 Castelló de la Plana

www.uji.es·comunicacio@uji.es

Tel. 964728833

Dipòsit legal: CS 302-2013

http://dx.doi.org/10.6035/Llico.2013.2014

Imprimeix: Innovació Digital Castelló, s.l.u. 


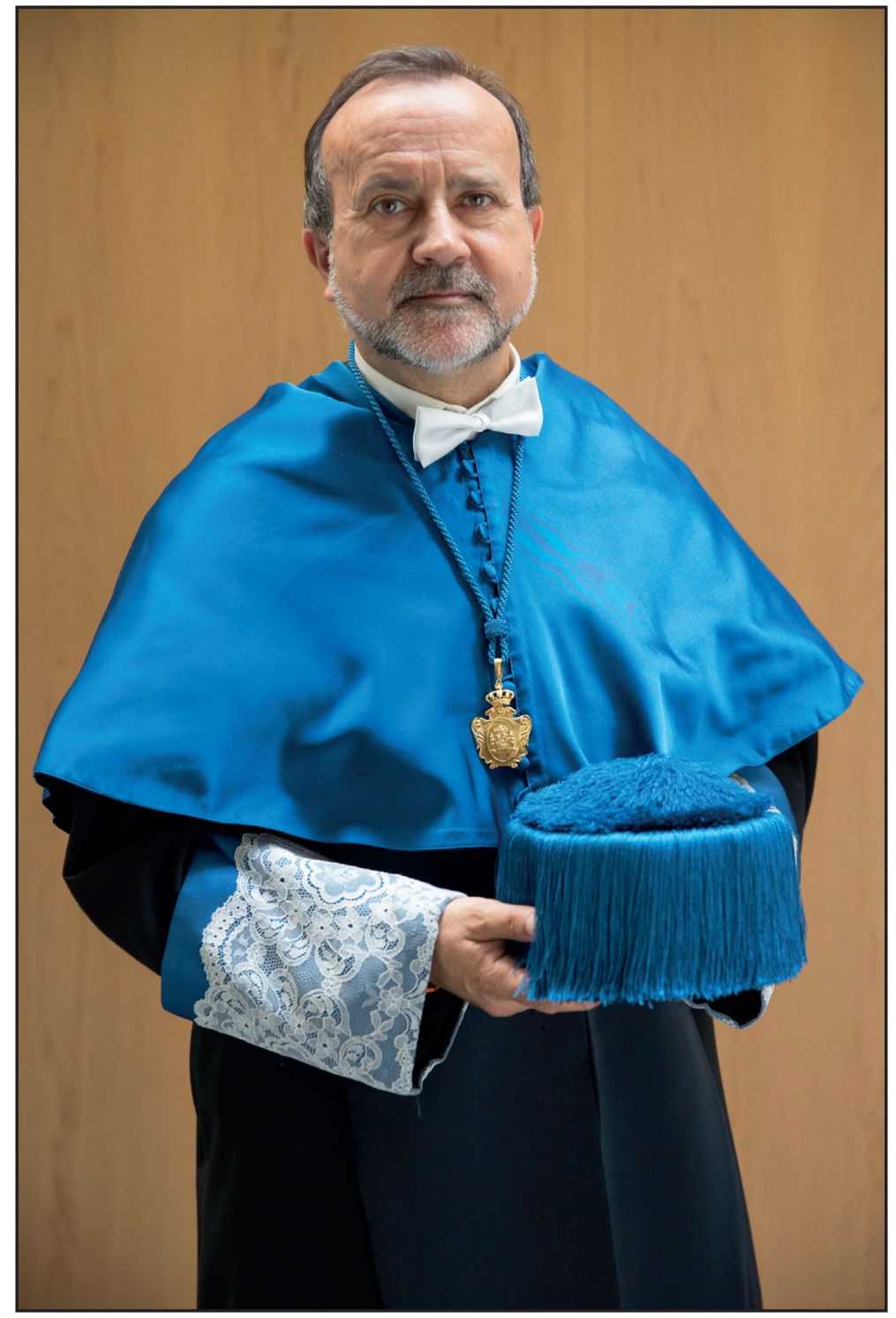




\section{QUÍMICA ANALÍTICA \\ I SALUT PÚBLICA}

\section{INTRODUCCIÓ}

Bon dia a tots i a totes: amics i amigues, companys i companyes, col-legues de professió; autoritats civils i acadèmiques.

Vull expressar-vos, en primer lloc, la gran emoció que sent en aquest moment i el profund agraïment al nostre rector, professor Vicent Climent, benvolgut amic i company en múltiples etapes en aquesta Universitat, en la qual hem tingut l'oportunitat de viure, en primera persona, l'evolució que ha tingut des de la dècada dels 80 quan ambdós, ben joves, ens incorporem al Col.legi Universitari de Castelló, el CUC.

Voldria, així mateix, abans d'entrar en el tema objecte d'aquesta lliçó inaugural, fer-vos partícips dels sentiments que he experimentat des del moment en què vaig tindre el privilegi de ser convidat a impartir aquesta Iliçó inaugural. Han estat molts els records que s'han amuntonat en la meua memòria en els últims dies.

Va ser en l'estiu de 1979 quan vaig rebre una telefonada del Ilavors director del CUC, professor Agustín Escardino, per a indicar-me que havia estat seleccionat per a ocupar la plaça d'ajudant de Química General. A l'octubre de 1979 em vaig traslladar des de Sòria, la meua terra natal, fins a Castelló. 
Iniciava, així, la meua carrera universitària, primer al CUC i, posteriorment, des que es va crear, a I'UJI.

En aqueixa època no es realitzava cap tipus d'investigació experimental al CUC i, he de confessar-ho, vaig passar dos anys fantàstics, en els quals únicament em vaig dedicar a impartir les meues classes de Laboratori de Química General i a gaudir del meu primer treball i del meu temps lliure. Alumnes meus d'aqueix any són ara vicerectors d'aquesta Universitat. Com passa el temps!

Transcorreguts aqueixos dos primers anys de relativa relaxació, vaig comprendre que havia de realitzar la meua tesi doctoral. Jo no provenia de la Universitat de València, font de quasi tots els professors i professores del CUC en aqueixos anys, ni m'hi sentia vinculat. La meua aposta va ser clara: volia fer la tesi al CUC. No hi havia instal-lacions adequades, ni no ningú més que realitzara investigació experimental; però, així $i$ tot, no vaig tindre dubtes. El meu lloc de treball estava a Castelló i ací era on jo realitzaria la meua tesi doctoral. Va ser llavors quan vaig contactar amb un dels tres únics professors del CUC (adjunts, agregats o catedràtics), amb capacitat per a dirigir una tesi doctoral en l'àmbit de ciències, i li vaig plantejar la idea de realitzar aquest treball, a Castelló, sota la seua direcció.

Va nàixer llavors una relació entranyable, professional i humana, amb el meu benvolgut amic i mestre, professor Julio Medina, qui lamentablement uns anys després ens va abandonar com a conseqüència d'un càncer implacable, a una edat insuportablement precoç. Es va iniciar una etapa complicada, però plena d'emocions i de reptes. Gràcies a l'ajuda de Petromed (avui British Petroleum), aconseguírem finançament per a comprar un senzill espectrofluorímetre, del qual no em vaig separar en tres anys. S'hi va habilitar un xicotet habitacle a un dels laboratoris docents, es va comprar el material i els reactius necessaris — he de dir que tot molt senzill- i vaig passar a dedicar-hi tres anys de la meua vida tancat unes vuit hores diàries, en solitari, en aqueix improvisat laboratori.

Però va merèixer la pena. Al novembre de 1984 vaig defensar la meua tesi doctoral en l'àmbit de la química analítica. Va ser la primera tesi, la part experimental de la qual es va realitzar al CUC. I l'acte de defensa va resultar ser tot un esdeveniment en aqueixos anys. Una aula docent de més de 100 persones era de gom a gom. Totes les persones que, d'una manera o una altra, m'havien acompanyat durant aqueixos anys eren allà per a mostrar-me el seu suport: Manolo «el del bar», Toni «el de la fotocopiadora», els bidells 
Ramiro i Eugenio; les dones de fer feines Manolita i Carmen, Julio Tena Andrés, I'omnipresent Isauro, alumnes, personal de secretaria, etc. Potser no era l'ambient científic habitual en la defensa d'una tesi doctoral (encara que també n'hi havia), però certament s'hi respirava una atmosfera plena d'il.lusió, entusiasme, i amb grans expectatives davant d'un futur que es presentava prometedor. Amb escassos mitjans i mètodes analítics poc sensibles i selectius ens vam atrevir a investigar la presència d'alguns metalls en aigües mitjançant tècniques fluorimètriques. Eren uns temps en què les presentacions a congressos les finançàvem de la nostra pròpia butxaca i els mitjans eren molt escassos. A pesar de les dificultats, vam ser capaços de publicar diversos articles científics en revistes internacionals de prestigi, i suplíem la falta de tradició i de coneixement d'anglès científic, entre unes altres carències, amb grans dosis d'imaginació, il.lusió i treball.

Van ser els inicis de la química analítica mediambiental al CUC. A poc a poc avançàvem en aquest àmbit. Vam aconseguir de comprar un equip d'absorció atòmica i dos cromatògrafs de gasos — per descomptat amb columnes de vidre reblertes - amb els quals iniciàrem els nostres primers treballs sobre contaminació del medi marí. Julio Medina va tindre l'encert d'aconseguir un important contracte del Programa de les Nacions Unides per al Medi Ambient en el pla d'acció per al Mediterrani (Programa MEDPOL). Us parle dels anys 1982-1988, durant els quals un grup molt reduït de gent jove, dirigit pel professor Julio Medina, ens vam dedicar a fer disseccions de peixos, musclos, gambes, sardines... per a analitzar-hi els nivells de metalls pesants i plaguicides organoclorats. Els mitjans eren escassos —els d'aqueixa època - i qualsevulla anàlisi requeria una àmplia manipulació de mostra. Tot allò queda molt lluny de les sofisticades tecnologies actuals, però encara així vam ser capaços de reportar dades sobre nivells de mercuri o plom, entre altres metalls, de plaguicides organoclorats com el DDT, i de bifenils policlorats $(\mathrm{PCB})$, en organismes marins i en sediments del litoral valencià. Crec que hi vam estar a l'altura de les circumstàncies.

De manera breu he volgut emprar-hi el meu propi cas i els canvis experimentats des de l'any 1980 en l'àrea de QA d'aquesta Universitat per a il.lustrar, amb un exemple pròxim, l'evolució d'aquesta àrea de coneixement en l'àmbit del medi ambient. Perquè, al cap i a la fi, és un clar reflex d'allò que s'ha esdevingut en molts altres llocs en les últimes dècades. Des de la investigació en solitari de metalls en aigües amb l'ús de mètodes laboriosos i poc sensibles, o les rudimentàries anàlisis d'uns pocs contaminants orgànics 
en el medi ambient (dècada dels 80 , al CUC), fins a la investigació de cents, de milers de contaminants en tot tipus de mostres, amb tècniques extraordinàriament poderoses, en el moment actual, amb un equip de treball d'uns 30 investigadors (Institut Universitari de Plaguicides i Aigües —IUPA— a I'UJ).

Al llarg de tots aquests anys, en els quals s'ha produït la transició del CUC a I'UJl, ha estat també fonamental la col.laboració internacional. Érem conscients que, per a avançar, calia col-laborar amb uns altres investigadors dels qui tinguérem quelcom a aprendre. He de citar ací l'extensa col·laboració en la dècada dels $90 \mathrm{amb}$ el RIVM holandès, amb el grup de treball dirigit pel doctor Elbert Hogendoorn, excel-lent investigador i millor persona, de qui vam aprendre no només interessants aplicacions d'acoblaments LC-LC, en els quals era pioner, sinó també el gust per la investigació i la importància de l'honestedat i del treball ben fet.

Però existeix també un altre factor decisiu en la nostra evolució com a grup d'investigació: el suport mutu i continuat durant tots aqueixos anys d'un altre investigador del CUC, amb qui, junts, vam construir el Laboratori de Medi Ambient i Recursos Naturals, base de l'actual IUPA. La faceta personal ha estat ací fonamental, perquè entre dos amics, que s'entenen, s'aprecien i es respecten, és molt més senzill portar endavant aquesta tasca i, a més, resulta fins i tot divertit. El nostre grup d'investigació no seria el que actualment és si el professor Ignacio Morell no haguera estat des del principi amb mi. Gràcies, Ignacio, pels molts i molt bons moments que hem compartit.

La química, en general, i la química analítica, en particular, han experimentat espectaculars avanços en les últimes dècades. Pareixen llunyans els temps en què, sobre la base de reaccions químiques bàsiques, amb uns pocs tubs d'assaig, reactius poc sofisticats, i senzills aparells, els químics analítics realitzàvem anàlisis de tipus qualitatiu, útils, però molt limitades. Érem capaços de saber si una mostra contenia ferro, cobalt, alumini, o uns altres elements comuns i, com a màxim, fer una estimació semiquantitativa. La majoria de mètodes quantitatius d'anàlisi estaven basats en tècniques òptiques o electroanalítiques, molt bàsiques. Difícilment es podien afrontar problemes de tipus mediambiental o de seguretat alimentària, en els quals els continguts de contaminants són normalment extremadament baixos, lluny de les possibilitats analítiques que oferien les tècniques d'aqueixa època. Pareix tot açò molt llunyà, en efecte, però a penes han transcorregut tres dècades, com us acabe de relatar. 
Al llarg d'aquesta lliçó m'agradaria mostrar-vos algunes idees sobre les contribucions de la QA en l'àmbit de la salut pública, en particular sobre dos aspectes que considere fonamentals: medi ambient i seguretat alimentària. Em referisc a la presència de contaminants, residus i additius prohibits en aigües, sòls, aire o aliments, aspectes que estan íntimament lligats a la nostra qualitat de vida. 


\section{QUÍMICA ANALÍTICA I SALUT PÚBLICA}

Podríem definir salut pública com la disciplina encarregada de la protecció de la salut poblacional. La investigació en aquest àmbit és un exemple paradigmàtic de treball multidisciplinari, amb la participació d'especialistes en medicina, biologia, química, toxicologia, sociologia i veterinària, entre altres àrees del coneixement.

Algunes àrees d'investigació rellevants en salut pública són l'impacte de l'ambient en la salut, malalties minoritàries, investigació en vacunes, genòmica i salut, seguretat alimentària, entre altres. Només tractaré ara d'aqueixes activitats relacionades íntimament amb la química analítica, principalment amb els laboratoris de salut pública, organismes imprescindibles per al control de qualitat d'aliments, aigües, sòls i aire. Destaquen dues àrees, per la importància que tenen: salut i medi ambient i seguretat alimentària, en les quals la química analítica juga un paper fonamental, i que no poden entendre's sense una labor altament especialitzada. Disciplines de treball que només poden abordar-se amb l'ús d'acoblaments instrumentals poderosos, com ara cromatografia/espectrometria de masses, als quals em referiré, breument, més avant.

Però, aquesta situació no sols ocorre en aquests àmbits, els quals he triat com a representatius de la rellevància de la QA moderna. Molts altres tampoc poden entendre's sense aquest tipus d'instrumentació. Em referisc al control del dopatge en l'esport (control antidopatge), anàlisi toxicològica, o l'anàlisi forense, entre altres, on els laboratoris s'enfronten contínuament a reptes analítics consistents a identificar els compostos causants d'un dopatge, d'una intoxicació, o fins i tot d'una mort. Àmbits apassionants, que no res tenen a veure amb l'anàlisi de rutina, sinó més aviat amb una investigació exhaustiva i complicada.

Són freqüents les alertes ambientals i de seguretat alimentària que, sens dubte, generen una gran alarma social. La majoria de les quals són possibles gràcies a l'enorme potencial i espectaculars avanços experimentats per la QA, ja que un bon laboratori especialitzat és, avui en dia, capaç de detectar pràcticament qualsevol problema relacionat amb la presència de contaminants i productes prohibits d'origen antropogènic.

Cada vegada és major la informació sobre la composició de tot allò que ens envolta. Amb les modernes tècniques analítiques som capaços de detectar i identificar de manera absolutament fiable compostos indesitja- 
bles a uns nivells de concentració sorprenentment baixos, la qual cosa era impossible d'imaginar fa tan sols uns anys. Avui en dia sabem que en les aigües dels nostres rius, en l'aire que respirem, o en el nostre propi cos, se'n troben nombrosos contaminants que, segurament també estaven presents fa dècades, encara que no érem capaços de detectar-los llavors, o ni tan sols ens plantejàvem d'analitzar-los. Amb les tècniques analítiques més poderoses en mans d'investigadors i investigadores especialitzats podem detectar nivells de concentració de l'ordre de ppq (parts per quadrilió), és a dir, 1 pg/L equivalent a $1 \mathrm{~g}$ en 1012 litres (bilió), i fins i tot menors.

Amb aquest nivell del coneixement, no hi ha riu, llac o mar que quede lliure de contaminació. Actualment, no ens sorprèn trobar traces de fàrmacs, drogues d'abús, o productes d'atenció personal, en les aigües. Açò és lògic i esperable. El realment sorprenent seria que no s'hi trobaren, atès l'ampli ús que en fem.

Amb tota la informació de què avui disposem, sorgeixen algunes preguntes a les quals hem de donar resposta: Són compatibles els avanços tecnològics, el progrés i el consum exagerat, amb un medi ambient saludable i segur? És possible un ús sostenible de productes químics que, sens dubte, milloren la nostra qualitat de vida, i que, al mateix temps, puguem gaudir d'un planeta no contaminat? Podem continuar contaminant, abocant al medi ambient tot allò que ens sobra, o ens molesta, sense reciclar, tractant al planeta com si fóra un albelló sense fi? Crec que la resposta és evident.

En la situació actual, necessitem un canvi conceptual, una major cultura ambiental i, en seguretat alimentària, una major implicació. Al meu parer, hauríem de ser capaços d'assimilar que convivim amb productes químics de síntesi, els quals han suposat grans avanços i ens han proporcionat una major qualitat de vida. Això és innegable. Però, al mateix temps, hauríem d'entendre que açò comporta la presència pràcticament ubiqua de milers de compostos d'origen antropogènic al nostre planeta.

Com deia la nostra estimada companya, professora Purificación Escribano, en la seua lliçó inaugural de fa dos anys:

Hi ha un altre aspecte que, derivat de l'activitat intrínseca dels mateixos químics, ha contribuït a aquesta identificació de la química amb un perill soterrat. I és la contínua millora de les tècniques analítiques. Gràcies a aquests resultats, hi ha la percepció per part de la societat d'una aparent contaminació de quasi tot el que usem, mengem... Substàncies perilloses apareixen en anàlisi realitzada en aliments i en l'ambient, causant una evident alarma 
social. I aquest és un assumpte en què es necessita una urgent alfabetització de la població.

Pareix necessari, per tant, aconseguir un equilibri raonable i realista, però amb un cert grau d'utopia, la qual cosa sempre és bona, de manera que la ciutadania exigim controls i responsabilitats davant dels excessos. Segurament no és possible viure en un món absolutament net, amb nivell «zero» de contaminants i residus químics. Però, el que sí que és possible, i també desitjable, és que es dispose de la màxima informació per a poder valorar la situació, ja que només des del coneixement es pot donar resposta als nombrosos problemes de contaminació als quals ens enfrontem. El desconeixement, la falta de dades, porta a l'abús, a la ignorància, i a plantejaments equivocats. Quantes vegades $m$ 'he trobat, al llarg de la meua carrera professional, amb situacions absurdes, de negar l'evidència, de banda de persones amb certes responsabilitats en la gestió ambiental, que pretenien, amb una falta de criteri evident, que no es detectara cap contaminant en les aigües, perquè entenien que si apareixia algun tipus de contaminació, llavors sorgirien els problemes! I no entenien/entenen que els problemes estan ací, ho vulguen o no. I, pitjor encara, he patit l'experiència de veure cancel.lats projectes ambientals importants perquè els resultats evidenciarien la contaminació de les aigües, la qual cosa no interessava a l'Administració. I hauria de ser just tot el contrari!

És llavors quan es troba a faltar una major educació ambiental. He de reconèixer que sent una certa enveja de països del nostre entorn que no tenen cap problema a fer públiques les dades dels controls realitzats, encara que els resultats demostren que hi ha contaminació, o no siguen políticament rendibles. A Espanya, la situació ha millorat en els últims anys, però no prou. Encara continuem arrossegant aqueixa por a la dada. No sabem manejar-ho. Ens espantem i volem amagar-ho. Què gran error!

Moltes alertes ambientals estan relacionades amb catàstrofes, com van ser la ruptura de l'embassament d'Aznalcóllar, que va produir una greu contaminació per metalls; desastres ecològics relacionats amb accidents de petroliers; fugues de radioactivitat com la recentment ocorreguda al Japó. Alertes alimentàries n'hi ha de diversos tipus i origen, i poden estar relacionades amb agents biològics (virus, bacteris, paràsits, prions), o amb agents químics (contaminants i residus de molt diversos tipus). 
Em referiré, en aquesta lliçó, al segon cas, és a dir, a aqueixes alertes relacionades amb la presència de compostos químics perillosos, tant en els aliments com en el medi ambient. Alguns casos possiblement us resultaran coneguts: presència de melamina en productes lactis i aliments infantils; dioxines en la carn de pollastre; plaguicides prohibits en aliments, incloenthi els infantils (potets); antibiòtics o clenbuterol en la carn.

De vegades ha estat complicat detectar el problema, perquè generalment era inesperat, i els laboratoris de control no incloïen aqueixes determinacions en les anàlisis rutinàries. El grau d'imaginació i la falta d'escrúpols de certes persones a l'hora d'adulterar un aliment per a obtenir beneficis són inimaginables. Per això, moltes vegades els laboratoris ni tan sols arriben a sospitar que un cert compost pot haver-se afegit intencionadament a un aliment i, lògicament, és difícil descobrir-ho.

Açò em porta a plantejar-vos quina és la realitat dels laboratoris analítics de control mediambiental i de seguretat alimentària (Ibáñez, 2012).

\section{INVESTIGACIÓ DE COMPOSTOS DIANA (TARGET ANALYSIS) I DE COMPOSTOS DESCONEGUTS (NON-TARGET ANALYSIS)}

En primer lloc, cal aclarir que no hi ha mètodes universals d'anàlisi capaços de detectar tot tipus de contaminants en tot tipus de mostres. Si bé, la determinació de metalls (els quals es troben entre els contaminants prioritaris) pot afrontar-se pràcticament amb una aproximació universal, amb tècniques com ICP-MS, no obstant això l'àmbit de contaminants orgànics és molt més complex. La QA s'enfronta a la determinació de milers de compostos, molts d'aquests desconeguts, els quals normalment es troben a baixes concentracions.

La qüestió que sorgeix llavors és la següent: Si no es poden investigador «tots» els compostos, quins s'han de seleccionar per al control? Us diré que aquesta selecció ja es fa en molts casos, i que és el resultat d'anys d'investigació. Hi ha nombrosos llistats de contaminants prioritaris per al control ambiental i alimentari. Les legislacions vigents indiquen els compos- 
tos que han de determinar-se en cada cas. Però, evidentment, en queden molts altres sense investigar.

A manera d'exemple, es pot citar la legislació sobre aigües potables, que estableix les anàlisis que han de realitzar-s'hi, la periodicitat, els compostos que han d'incloure-s'hi i els límits màxims permesos (Council Directive 98/83/ $E C)$. La relativa a plaguicides en aliments, la qual estableix els límits màxims de residus (LMR) (Regulation EC 396/2005) o els criteris de qualitat en anàlisi de residus de plaguicides (Sanco Document /12495/2011). La legislació sobre mètodes analítics per a contaminants en aliments d'origen animal (European Commission Decision 2002/657/CE) o sobre els nivells màxims permesos en aliments (Commission Regulation (EC) 1881/2006).

La legislació avança lentament a mesura que coneixem més dades. És habitual que els químics analítics alertem sobre la presència de certs contaminants en el medi ambient i que anys més tard s'aprove nova legislació respecte d'això, a la llum de les dades obtingudes.

En la situació actual els laboratoris treballen sobre llistats de compostos «diana», aplicant-hi mètodes que, com a màxim, són capaços de determinar 100 o 200 compostos, amb molt rares excepcions. Això és el que en l'argot analític es coneix com a anàlisi target. Però amb aquesta aproximació queda sense investigar un elevat nombre de contaminants, molts d'aquests encara desconeguts, particularment els productes de transformació.

La cerca de compostos desconeguts, sense cap selecció prèvia, és el que coneixem com a anàlisi non-target. En aquest cas, estem encara lluny de poder donar una resposta satisfactòria en àrees com el medi ambient, on potencialment podem trobar-hi milers de contaminants, normalment a nivells de concentració molt baixos, però així i tot perillosos, en mostres que contenen uns altres components majoritaris que en dificulten l'anàlisi (Krauss, 2010; Hernández 2011a).

No cediré a la temptació d'explicar amb detall el fonament de les tècniques i mètodes que s'hi apliquen, perquè no s'escau en un acte com aquest, però creieu-me si us dic que l'anàlisi de compostos desconeguts a nivells de traça és molt complicat, i que les possibilitats d'èxit són escasses quan no hi ha cap tipus d'informació sobre la mostra objecte d'anàlisi, o sobre el problema a resoldre, que ens permeta de dirigir els nostres esforços.

Les investigacions analítiques en l'àmbit ambiental i de seguretat alimentària només poden realitzar-se, com us deia anteriorment, fent servir acoblaments cromatografia/espectrometria de masses. D'una banda, la cro- 
matografia permet la separació dels components de la mostra, de manera que es puga realitzar la detecció, identificació i quantificació del compost d'interès de manera més senzilla, amb menys interferències. D'altra banda, l'espectrometria de masses aporta informació sobre l'estructura del compost detectat, fonamental per a dur a terme una correcta identificació. Sens dubte, els espectaculars avanços de la MS han permès a la QA donar respostes a molts dels problemes actuals. Termes com triple quadrupol, temps de vol, QTRAP, ORBITRAP, formen part del lèxic usat en la QA moderna. Científics com ara J.J. Thomson, F.W. Aston, A.J. Dempster, A. Nier van ser fonamentals en els inicis i posterior desenvolupament de la MS. Les investigacions relatives a aquesta tècnica han estat reconegudes per la comunitat científica a arreu del món. Fins a cinc investigadors han estat guardonats al llarg de la història amb el premi Nobel pels seus èxits en l'àmbit de la MS (figura 1).

\section{苟延 University of 12. BRISTOL MASS SPECTROMETRY RESOURCE}

The History of Mass Spectrometry

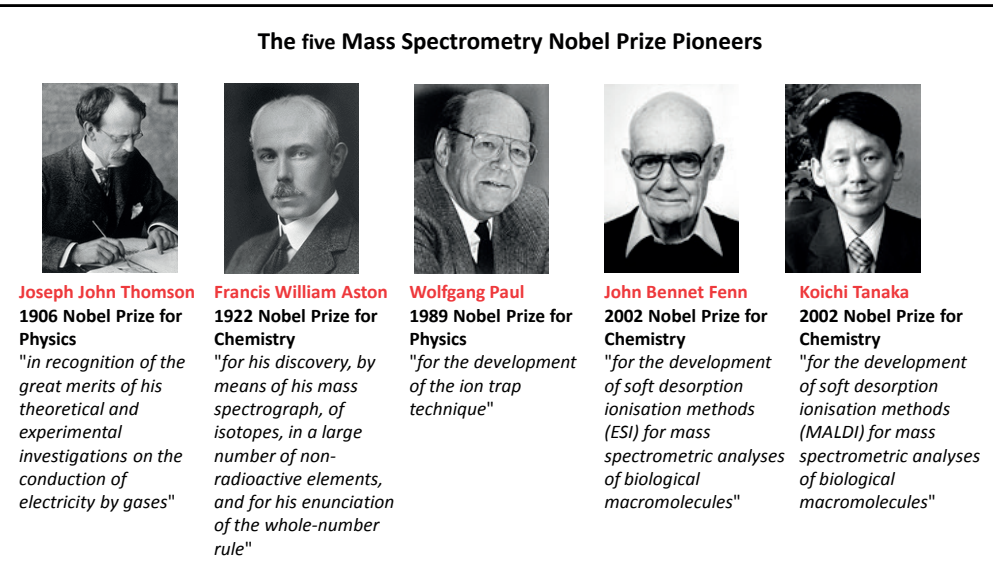

Fig. 1. Científics que han estat guardonats amb el premi Nobel per les seues aportacions en l'àmbit de l'espectrometria de masses

A pesar que no és possible analitzar «tots» els potencials contaminants d'una mostra, no ens resignem a treballar només amb llistes limitades de 
compostos. L'aproximació més raonable, en la qual treballem actualment els químics analítics, és la següent:

- Aplicació, en primer lloc, de mètodes d'ampli escombratge (screening) en els quals s'investiga la presència d'un nombre elevat de contaminants seleccionats, molt superior als de les anàlisis convencionals aplicades fins ara. En aquestes anàlisis, la finalitat és principalment qualitativa, és a dir, detectar i identificar els compostos presents en la mostra.

- Posterior aplicació de mètodes quantitatius d'anàlisi target per als compostos que s'hagen detectat en el screening previ, a fi de determinar els nivells de concentració.

- Òbviament, sense renunciar als mètodes que actualment s'apliquen en rutina per a complir amb els requisits legislatius sobre contaminants prioritaris.

La gran aposta de la química analítica moderna és, per tant, avançar cap a aqueix mètode ideal de screening «universal», en el qual seria possible detectar qualsevol contaminant que estiguera present en les mostres. Encara que aquest mètode no existeix, ens hi acostem.

Actualment es poden aplicar metodologies de screening basades en l'ús combinat de cromatografia de gasos i cromatografia líquida amb espectrometria de masses d'alta resolució (HRMS), que permeten detectar un nombre cada vegada més elevat de compostos target (actualment uns 2.000). A més, també dur a terme una aproximació non-target (cerca de desconeguts). Açò és possible gràcies a l'enorme potencial de la HRMS, que proporciona l'espectre complet de masses, amb elevat poder de resolució i mesures de massa exacta, tant de les molècules originals com dels fragments característics; informació molt valuosa que permet identificar, en principi, qualsevol component de la mostra que s'haja ionitzat en el procés de mesura.

Els mètodes qualitatius d'ampli screening - basats en cromatografia/ HRMS (Kaufmann, 2012; Hernández, 2012) — units a mètodes quantitatius molt sensibles - basats en acoblaments cromatografia/MS en tàndemaporten el coneixement necessari en àmbits tan diversos com ara medi ambient, seguretat alimentària, toxicologia, control antidopatge 0 anàlisi forense (Díaz, 2012; Peters, 2010; Hernández 2011b; Picó, 2008). 


\section{PROBLEMÀTICA MEDIAMBIENTAL}

Sembla que no és necessari insistir en la importància que per a nosaltres tenen l'aigua o l'aire. No podríem subsistir si aquests dos elements, absolutament indispensables, es veren fortament deteriorats. La nostra vida correria perill i és, per tant, la nostra obligació protegir-los de les múltiples amenaces que pateixen perquè, al cap i a la fi, som també els responsables de les dites amenaces.

Són paradigmàtics els casos en què un nou material o producte ha sorgit amb força, com un gran avanç de la societat. No obstant això, temps després, a mesura que hem millorat el nostre coneixement, s'ha demostrat que els beneficis venien també acompanyats de notables riscos. Crec interessant citar ací el que, a parer meu, va significar un abans i un després en la manera d'entendre el binomi benefici-risc en l'ús de compostos químics de síntesi. La publicació del Ilibre La primavera silenciosa, per Rachel Carson en 1962 (Carson, 1962), va posar de manifest els perills amagats associats a l'ús d'un producte que fins aleshores es considerava altament beneficiós, el DDT. Carson va donar el primer avís que el DDT s'havia difós per tot el planeta, i havia contaminat pràcticament tots els éssers vius, fins en les terres verges més remotes. Aqueix llibre, que va marcar una fita, va presentar proves de l'impacte d'aquest tipus de substàncies sintètiques sobre les aus i la resta de fauna silvestre, que va arribar, en alguns casos, a la pràctica extinció de certes espècies (figura 2). El DDT és un compost organoclorat descobert pel químic suís, Paul Hermann Müller, guanyador, en 1948, del premi Nobel de medicina precisament pel seu descobriment del DDT com a eficaç insecticida usat en el control de la malària i febre groga, i moltes altres infeccions causades per insectes vectors. En el segle XX va ser àmpliament utilitzat com a eficaç insecticida i, de fet, gràcies al DDT, els casos de malària van descendir dràsticament a nombrosos països. Després d'una campanya mundial (promoguda en gran manera per la publicació del llibre de Carson) que al-legava que aquest compost s'acumulava en les cadenes tròfiques i davant del perill de contaminació dels aliments, se'n va prohibir l'ús. Així, l'Agència de Protecció Ambiental dels Estats Units (EPA) va prohibir el DDT en 1972. 


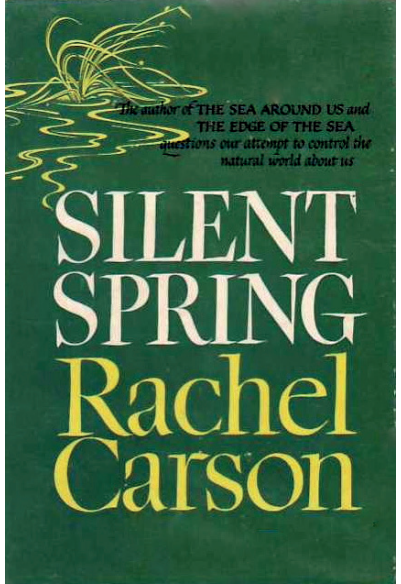

Fig. 2. Portada del Ilibre La primavera silenciosa de Rachel Carson. II.lustració i estructura química de l'insecticida organoclorat DDT, àmpliament usat en la dècada dels 60

Encara que el DDT no s'usa des de fa uns 40 anys en la immensa majoria de països, amb les tècniques analítiques actuals encara podem trobar quantitats residuals en el medi ambient, així com en el greix d'animals i dels éssers humans on s'acumula.

Hi ha altres exemples semblants al del DDT: compostos químics de síntesi que han tingut efectes beneficiosos per a la humanitat, però que anys després s'ha demostrat que també portaven associats efectes negatius no intencionats per al medi ambient i la salut. Cal citar els freons o compostos clorofluorocarbonis (CFC), els quals van sorgir davant de la necessitat de buscar substàncies no tòxiques que serviren com a refrigerants en aplicacions industrials. Thomas Midgley va descobrir, en 1930, que aquests gasos eren molt estables, poc reactius, i innocus per als sers humans, s'evitaven així milers d'intoxicacions accidentals. Atès que llavors no existia molta informació sobre l'ozó i es desconeixien els efectes perjudicials dels CFC, el mateix Thomas Midgley va morir-se pensant que havia fet un gran servei a la humanitat. 
Els CFC van substituir a compostos com a l'amoníac, clorometà, o diòxid de sulfur, com a refrigerants, els quals, encara que efectius, eren tòxics, inflamables i/o explosius. L'ús es va propagar ràpidament en els aires condicionats d'automòbils, neveres i indústries. A partir de 1950 es van començar a utilitzar també com a agents impulsors per a atomitzadors (esprais). Els CFC han jugat un paper decisiu en la conservació d'aliments i, per tant, en la lluita contra la fam al món. Doncs bé, anys després es va descobrir que aquests compostos eren uns dels principals causants de la destrucció de la capa d'ozó, la qual és fonamental per a la vida a la Terra perquè ens protegeix de la radiació UV tipus $B$, molt perillosa per als éssers vius. Anys més tard, els descobridors dels perills dels CFC per a la capa d'ozó (F. Sherwood Rowland, de la Universitat de Califòrnia; Mario J. Molina, de I'Institut de Tecnologia de Massachusetts (MIT); Paul Crutzen, de I'Institut Max Planck de Química de Mainz, Alemanya) van rebre, en 1995, el premi Nobel de química en reconeixement per les seues investigacions.

Un altre exemple són els bifenils policlorats (PCB), família de compostos organoclorats persistents formada per una sèrie de 209 congèneres, sintetitzats per primera vegada per Schmitt-Schulz, a Alemanya, en 1881. La producció de PCB a escala industrial la va iniciar, en 1929, l'empresa Monsanto. En principi, aquests compostos van ser benvinguts a causa de l'alta estabilitat tèrmica i resistència a la inflamabilitat que tenen, i s'utilitzaven com a olis lubricants, dielèctrics, fluids hidràulics, resines aïllants o pintures. L'ús de $P C B$ es va estendre, a mitjan segle $X X$, amb un màxim de producció a final de la dècada de 1970. Posteriorment, quan es van descobrir els perniciosos efectes sobre la salut, van ser prohibits a partir de 1986. Alguns PCB comparteixen una estructura química semblant i un mode d'acció tòxica amb les dioxines, uns dels compostos més tòxics que es coneixen. Altres efectes perillosos, com la disrupció endocrina i neurotoxicitat també estan associats amb els PCB.

Els PCB són molt estables i no es degraden fàcilment. Per això, es troben àmpliament difosos en el medi ambient. També és freqüent trobar PCB en diferents productes com la llet i derivats, teixit adipós (humà i animal) i altres òrgans amb contingut gras com el cervell i el fetge. 
M'agradaria recomanar-vos un llibre que em va inspirar i va animar a dirigir les meues investigacions cap a l'àmbit mediambiental i l'exposició de les persones a contaminants. Es tracta de Nuestro futuro robado, escrit per Theo Colborn, Dianne Dumanoski i Pete Myers, una obra que va reunir proves alarmants sobre el perill dels disruptors endocrins, compostos químics que suplanten a les hormones naturals, i trastornen els processos normals de reproducció i desenvolupament (Colborn, 1997). Aquest llibre, que vaig llegir quasi amb obsessió per la gravetat dels fets descrits i per com em resultava de pròxim, atesa a la meua professió, descriu nombrosos casos associats a greus problemes de contaminació, amb especial atenció als disruptors endocrins. El llibre explica com aquests contaminants han arribat a convertir-se part integrant de la nostra economia industrial, i s'han difós amb sorprenent facilitat per tota la Terra.

Moltes poblacions animals han estat afectades per aquestes substàncies, amb greus repercussions per a les aus, peixos, crustacis i mamífers, com la disfunció tiroïdal, disminució de la fertilitat, greus deformitats de naixement, anomalies metabòliques i del comportament, feminització de mascles, masculinització de femelles, i perill per als sistemes immunitaris. Aquest llibre obliga a plantejar-nos noves preguntes sobre les substàncies químiques sintètiques que hem escampat per tota la Terra.

Doncs bé, tots els fets mencionats certament han ocorregut, i segurament apareixeran casos semblants en el futur, perquè l'ànsia de fabricar productes de consum cada vegada més sofisticats i rendibles econòmicament porta, de vegades, a descuidar els possibles efectes negatius associats. Per això, el paper de la QA és fonamental: no només hem de controlar els contaminants «prioritaris», ja coneguts (Directiva 2000/60/EC; Directiva 2008/105/EC), sinó investigar també els productes de transformació o degradació en el medi ambient, així com altres contaminants desconeguts perquè es puga exercir un control sobre els mateixos (Hernández, 2011a). 
La figura 3 mostra alguns exemples rellevants de problemes de contaminació ambiental, entre els quals cal destacar-hi:

- La presència de dioxines i dibenzofurans clorats, els quals estan entre els compostos més tòxics coneguts, que es formen en diversos processos industrials, i que també són subproducte de la combustió incompleta de compostos orgànics que contenen clor (van Bavel, 2008).

- Els ja mencionats PCB i plaguicides organoclorats, considerats compostos prioritaris en el control ambiental.

- Els subproductes resultants de la desinfecció de les aigües quan són tractades amb clor, ozó, o cloramines. Aquests subproductes (ex.: cloroform i altres haloforms) es formen per reacció entre l'agent desinfectant i la matèria orgànica natural que hi ha en l'aigua. Ens podem veure exposats als mateixos no només a través de l'aigua potable, sinó també a través de la dutxa o dels banys en piscines (Lebeved 2012; Richardson 2012).

- Retardants de flama bromats (BRF), usats en ordinadors, mobles o tèxtils, per a millorar-ne la resistència al foc. Actualment preocupen els riscos que poden suposar per a la salut pública a causa de la persistència en el medi ambient. Arriben a contaminar l'aire, sòls i aigües. Aquests contaminants poden entrar també en la cadena alimentària, sobre tot en aliments d'origen animal, com el peix, carn, llet i productes derivats (Covaci, 2011). Tot això ha portat a la prohibició o restricció d'ús de certs BFR a la Unió Europea.

- Contaminants orgànics volàtils (ex.: multitud de dissolvents), metalls i compostos organometàl.lics, compostos perfluorocarburs (PCF). 


\section{Contaminants orgànics rellevants en el medi ambient (I)}

\begin{tabular}{|l|l|}
\hline Contaminant & Observacions \\
\hline $\begin{array}{l}\text { Dibenfo-p-dioxines clorades } \\
\text { (CDD) i dibenzofurans } \\
\text { clorats (CDF) }\end{array}$ & $\begin{array}{l}\mathbf{7 5} \text { CDD i } 135 \text { CDF congèneres. } \\
\text { El compost més tòxic és 2,3,7,8,-tetracloro-p-dibenzo dioxina (TCDD). } \\
\text { Determinació en matrius grasses, cendres, aigües i sediments. Es consideren POP. }\end{array}$ \\
\hline Bifenils policlorats (PCB) & $\mathbf{2 0 9}$ congèneres (16 prioritaris per a l'EPA). Considerats POP. \\
\hline $\begin{array}{l}\text { Plaguicides organoclorats } \\
\text { (OC) }\end{array}$ & $\begin{array}{l}\text { Aldrín, dieldrina, endosulfan, DDT, etc. } \\
\text { Pràcticament prohibits a tot el món. Formen part dels llistats prioritaris per la persistència } \\
\text { i perillositat que presenten. Considerats POP. }\end{array}$ \\
\hline $\begin{array}{l}\text { Subproductes de desinfecció } \\
\text { d'aigües (DBP) }\end{array}$ & $\begin{array}{l}\text { Es formen per reacció de desinfectants químics (clor, ozó, cloramina) amb la matèria } \\
\text { orgànica d'origen natural que hi ha en l'aigua. } \\
\text { Més de } 600 \text { DBP reportats: halometans (ex.: cloroform), haloàcids, haloaldehids, nitrosa- } \\
\text { mines, etc. }\end{array}$ \\
\hline Plaguicides & $\begin{array}{l}\text { Més de } 800 \text { matèries actives i milers de productes de transformació. } \\
\text { Determinació en aigües, sediments, sòls i aire. }\end{array}$ \\
\hline $\begin{array}{l}\text { Retardants de flama bromats } \\
\text { (BFR) }\end{array}$ & $\begin{array}{l}\text { Familia de nombrosos compostos, des dels tradicionals (PBD) fins als de nova generació } \\
\text { (NBFR). Emprats en multitud de productes de consum (aparells electrònics, tèxtil, mobles) } \\
\text { per a reduir la inflamabilitat del producte. S'alliberen en el medi ambient, són persistents i } \\
\text { acumulatius. Poden passar a la cadena alimentària, sobre tot als aliments d'origen animal. }\end{array}$ \\
\hline
\end{tabular}

\section{Contaminants orgànics rellevants en el medi ambient (II)}

\begin{tabular}{|l|l|}
\hline Contaminant & Observacions \\
\hline $\begin{array}{l}\text { Contaminants orgànics vo- } \\
\text { làtils (VOC) }\end{array}$ & $\begin{array}{l}\text { Compostos orgànics que es converteixen fàcilment en vapors o gasos. Alliberats per la } \\
\text { crema de combustibles com ara gasolina, fusta, carbó o gas natural. També els alliberen } \\
\text { dissolvents, pintures i uns altres productes emprats i emmagatzemats a la llar i en els llocs } \\
\text { de treball. Exemples coneguts són el benzè, formaldehid i uns altres dissolvents orgànics } \\
\text { com el toluè, xilè, acetona i percloroetilè (o tetracloroetilè), el principal dissolvent utilitzat } \\
\text { en la indústria de rentatge en sec. }\end{array}$ \\
\hline $\begin{array}{l}\text { Espècies inorgàniques (me- } \\
\text { talls i altres elements tòxics) }\end{array}$ & $\begin{array}{l}\text { Metalls prioritaris: Hg, Cd, Cr, Pb. } \\
\text { És important determinar les formes químiques específiques d'un element, a causa de la } \\
\text { diversa toxicitat i impacte ambiental (especiació). }\end{array}$ \\
\hline Perfluorocarburs (PFC) & $\begin{array}{l}\text { Compostos que tenen els hidrògens reemplaçats per fluor en una cadena carbonada. } \\
\text { Aplicacions molt interessants en l'electrònica, química i medicina. La gran utilització que } \\
\text { sén fa, amb l'elevada persistència expliquen la presència dels PFC en el medi ambient. } \\
\text { Tenen propietats bioacumulatives, per la qual cosa poden trobar-se també en el cos dels } \\
\text { éssers vius i en la cadena alimentària. Entre els més perillosos hi ha PFOA i PFOS, utilitzats } \\
\text { per a conferir resistència a l'aigua en teixits i aerosols, revestiments contra les taques, } \\
\text { revestiments lipofòbics en embalatges per a aliments, escumes extintores, etc. }\end{array}$ \\
\hline Contaminants emergents & \begin{tabular}{l} 
Fàrmacs, productes de cura personal, drogues d'abús, etc. En l'actualitat, sense regulació. \\
\hline
\end{tabular} \\
\hline
\end{tabular}

Fig. 3. Exemples de contaminants orgànics en el medi ambient

Alguns dels compostos mencionats estan considerats contaminants orgànics persistents (POP), I'ús dels quals està prohibit o molt restringit gràcies a I'acord internacional aconseguit en la Convenció d'Estocolm, firmat en 2001 i efectiu des de maig de 2004. Inicialment el llistat de POP el formaven 12 substàncies, i uns anys després es va ampliar amb nou substàncies o grups de substàncies més (figura 4). 
Conveni d'Estocolm sobre contaminants orgànics persistents (POP)*

\begin{tabular}{|c|c|c|}
\hline Annex & Nom & Excepcions \\
\hline A. Eliminació & Aldrín & Producció: no cap. Ús: insecticida i ectoparasiticida local. \\
\hline A. Eliminació & Clordà & $\begin{array}{l}\text { Producció: parts registrades. } \\
\text { Ús: ectoparasiticida local, insecticida, termiticida (incloent-hi edificis, } \\
\text { represes i camins) i com additiu per a adhesius de contraxapats. }\end{array}$ \\
\hline A. Eliminació & Dieldrin & Producció: no cap. Ús: operacions agrícoles. \\
\hline A. Eliminació & Endrin & No cap. \\
\hline A. Eliminació & Heptaclor & $\begin{array}{l}\text { Producció: no cap. } \\
\text { Ús: termiticida (incloent-hi l'estructura dels habitatges i metro), per al } \\
\text { tractament orgànic i en caixes de cablejat subterrani. }\end{array}$ \\
\hline $\begin{array}{l}\text { A. Eliminació i } \\
\text { C. Producció no } \\
\text { intencionada }\end{array}$ & Hexaclorobenzè & $\begin{array}{l}\text { Producció: parts registrades. } \\
\text { Ús: com a intermediari químic i dissolvent per a plaguicides. }\end{array}$ \\
\hline A. Eliminació & Mirex & $\begin{array}{l}\text { Producció: no cap. } \\
\text { Ús: termiticida. }\end{array}$ \\
\hline A. Eliminació & Toxafè & No cap. \\
\hline $\begin{array}{l}\text { A. Eliminació i } \\
\text { C. Producció no } \\
\text { intencionada }\end{array}$ & Bifenil policlorat (PCB) & Producció: no cap. \\
\hline B. Restricció & DDT & $\begin{array}{l}\text { Vector control de malalties d'acord amb la part II, annex B. } \\
\text { Producció i ús com a intermediari en producció de dicofol i uns altres } \\
\text { compostos. }\end{array}$ \\
\hline $\begin{array}{l}\text { C. Producció no } \\
\text { intencionada }\end{array}$ & $\begin{array}{l}\text { Dibenzo p-dioxines policlorades } \\
\text { i dibenzofurans policlorats }\end{array}$ & \\
\hline
\end{tabular}

*Firmat en 2001. Va entrar en vigor en maig de 2004.

Conveni d'Estocolm sobre contaminants orgànics persistents (POP)**

\begin{tabular}{|l|l|l|}
\hline Annex & Nom & Excepcions \\
\hline A. Eliminació & Alfa hexaclorociclohexà & No cap. \\
\hline A. Eliminació & Beta hexaclorociclohexà & No cap. \\
\hline A. Eliminació & Clordecona & No cap. \\
\hline A. Eliminació & Hexabromobifenil & No cap. \\
\hline A. Eliminació & $\begin{array}{l}\text { Ėter d'hexabromobifenil i èter } \\
\text { d'heptabromodifenil }\end{array}$ & $\begin{array}{l}\text { Producció: no cap. } \\
\text { Ús: reciclatge i reutilització d'articles que contenen aquests compostos. }\end{array}$ \\
\hline A. Eliminació & $\begin{array}{l}\text { Lindane } \\
\text { (Gamma hexaclorociclohexà) }\end{array}$ & $\begin{array}{l}\text { Producció: no cap. } \\
\text { Uarrmac en salut pública per a controlar la pediculosi i la sarna, com a } \\
\text { tractament de segona línia. }\end{array}$ \\
\hline $\begin{array}{l}\text { A. Eliminació i } \\
\text { C. Producció no } \\
\text { intencionada }\end{array}$ & Pentaclorobenzè & No cap. \\
\hline A. Eliminació & $\begin{array}{l}\text { Ėter de tetrabromodifenil i èter } \\
\text { de pentabromodifenil }\end{array}$ & $\begin{array}{l}\text { Producció: no cap. } \\
\text { Ús: reciclatge i reutilització d'articles que contenen aquests compostos. }\end{array}$ \\
\hline B. Restricció & $\begin{array}{l}\text { Acid sulfònic de perfluorooctà } \\
\text { (PFOS), les sals derivades i } \\
\text { fluorur de sulfonil perfluorooctà } \\
\text { (PFOSF) }\end{array}$ & $\begin{array}{l}\text { Producció: usos autoritzats. } \\
\text { Usos: diversos, en la part III de l'annex B. }\end{array}$ \\
\hline
\end{tabular}

**Contaminants afegits en la Quarta Conferència de les Parts, maig de 2009.

Fig. 4. Contaminants orgànics persistents regulats en el Conveni d'Estocolm (2001)

A més a més, cal afegir-hi una nova manera d'entendre la contaminació del medi ambient: els contaminants emergents, molts d'aquests com a conseqüència de l'ús que en fem en la nostra vida quotidiana (fàrmacs, productes d'atenció personal com ara filtres solars o repel-lents d'insectes), 
incloent-hi també les drogues d'abús. Aquests contaminants es troben encara sense regular en el medi ambient; però, amb les dades ja disponibles sobre la presència en les aigües, segurament seran tinguts en compte aviat en la legislació (ex.: nivells màxims permesos en aigües) (Farré, 2012; Buchberger, 2011; Hernández, 2007).

Com podem observar-hi, els químics analítics hem d'enfrontar-nos a múltiples problemes. Actualment hi ha el coneixement i la tecnologia adequats per a abordar pràcticament qualsevol problemàtica ambiental que puga aparèixer des de la perspectiva de la QA. Per tant, és qüestió de prioritats establir o no programes ambiciosos de control i d'investigació. Per a això, es requereixen fortes inversions en investigació i una aposta decidida per la defensa del medi ambient. Les metodologies d'ampli screening troben l'aplicació per excel-lència en l'àmbit del medi ambient, on potencialment es pot trobar tot tipus de contaminants, de molt diversa composició química, amb un nombre elevat de productes de transformació (Portolés, 2007; Kaufmann, 2012; Hernández 2011b).

Us mostre, a continuació, alguns exemples, els quals serveixen per a il.lustrar el mode de treball dels químics analítics. La figura 5 mostra la detecció de l'antibiòtic trimetoprim en aigua residual urbana per mitjà de screening amb tècniques de HRMS (LC-QTOF MS). La presència d'un pic cromatogràfic amb la mateixa massa exacta que el trimetoprim en una aigua residual urbana indica que aquest compost pareix estar present en la mostra. Aquest fet, unit a la coincidència en el temps de retenció amb el patró de referència i a la presència de fragments característics d'aquesta molècula en l'espectre de massa, indica clarament que la mostra d'aigua residual conté aquest antibiòtic. En aquest cas, en concentració elevada ateses les intensitats del senyal obtingut.

Un altre exemple és la detecció del fàrmac valsartan (figura 6), usat per al tractament de la hipertensió arterial, recollit en un llistat de més de 1.000 compostos investigats per mitjà de tècniques de screening. La poderosa informació aportada per la tècnica LC-QTOF MS permet identificar de manera temptativa aquest compost, sense disposar-ne tan sols del patró de referència, perquè els espectres de masses a alta baixa i alta energia mostren la presència de la molècula amb la massa exacta de la mateixa, així com de fragments característics, els quals difícilment podrien procedir de cap altre compost. L'adquisició posterior del patró de referència ens va permetre confirmar de manera absolutament fiable la presència d'aquest fàrmac en 
les aigües. L'opció d'investigar contaminants molt diversos, sense necessitat disposar, a priori, del patró de referència obri interessants perspectives mediambientals.

\section{Detecció de l'antibiòtic trimetoprim en aigües residuals}

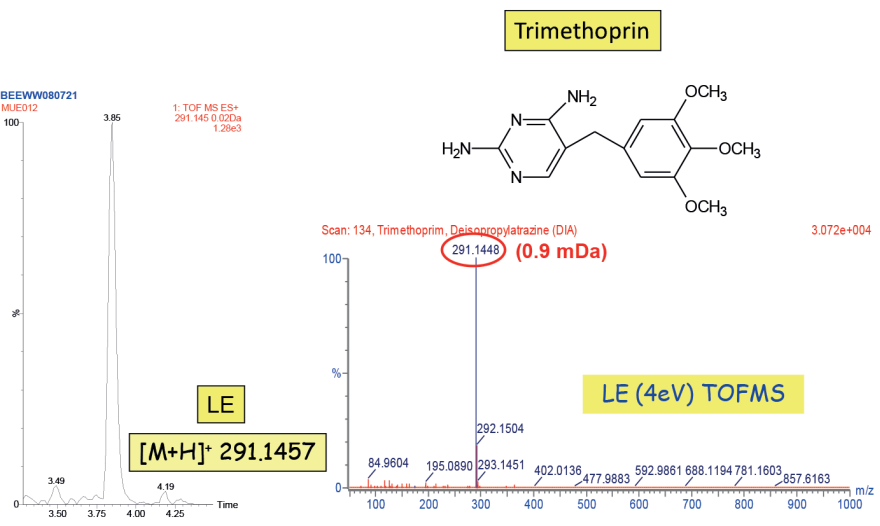

$\Delta R T$ (sample-standard) $=0.07 \mathrm{~min}$

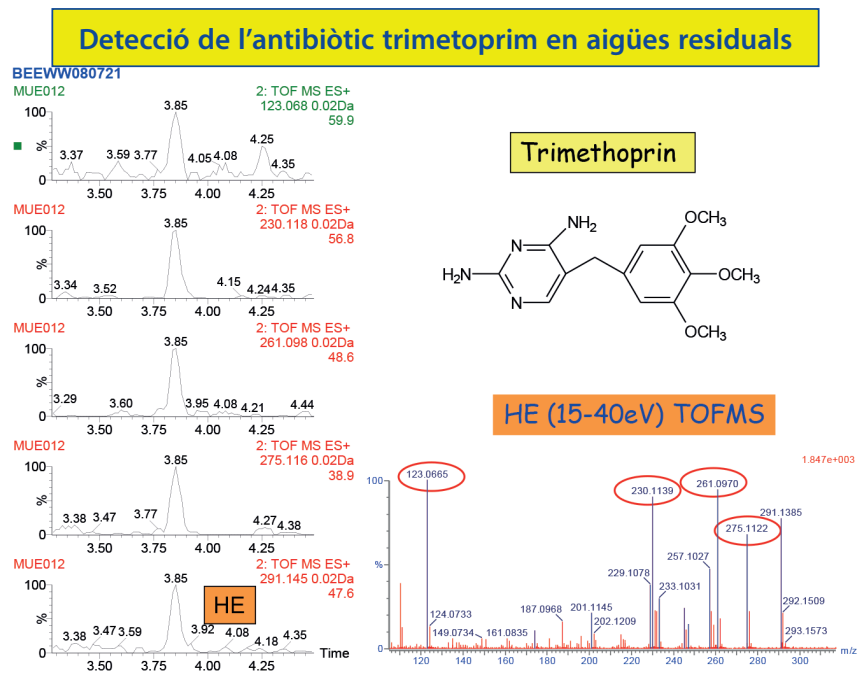

Fig. 5. Detecció de l'antibiòtic trimetoprim en aigües residuals urbanes per mitjà de LC-QTOF MS 


\section{Detecció del fàrmac valsartan en efluent urbà}

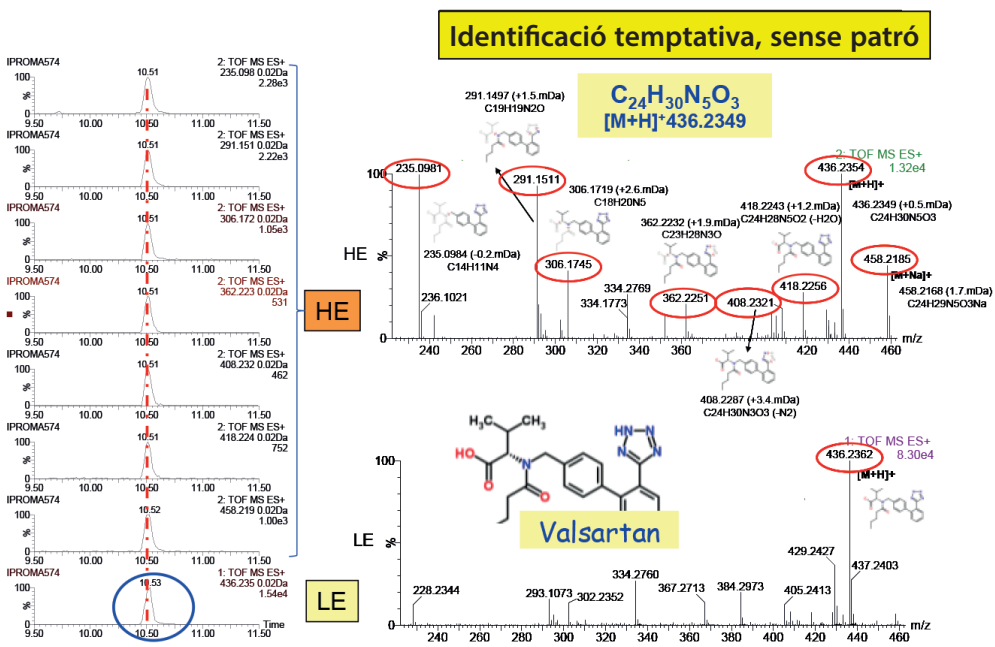

Fig. 6. Detecció del fàrmac valsartan en aigües residuals urbanes per mitjà de LC-QTOF MS

La figura 7 mostra resultats recents d'un screening qualitatiu realitzat en aigües superficials i subterrànies de la província de Castelló. Pot observar-s'hi l'elevada freqüència de detecció de plaguicides, especialment herbicides de la família de les triazines, i dels TP d'aquestes, la qual cosa era d'esperar ja que aquestes mostres estan preses en zones d'intensa activitat agrícola. A més de plaguicides, també s'hi detecten diversos fàrmacs, i fins i tot el principal metabòlit de la cocaïna, la qual cosa demostra que aquests compostos no només es troben en les aigües residuals, sinó que també arriben fins al medi ambient aquàtic. Aquests resultats no són exclusius de Castelló. Estudis realitzats en unes altres zones d'Espanya han mostrat dades semblants pel que fa a tipus de contaminants detectats i freqüència de detecció. 

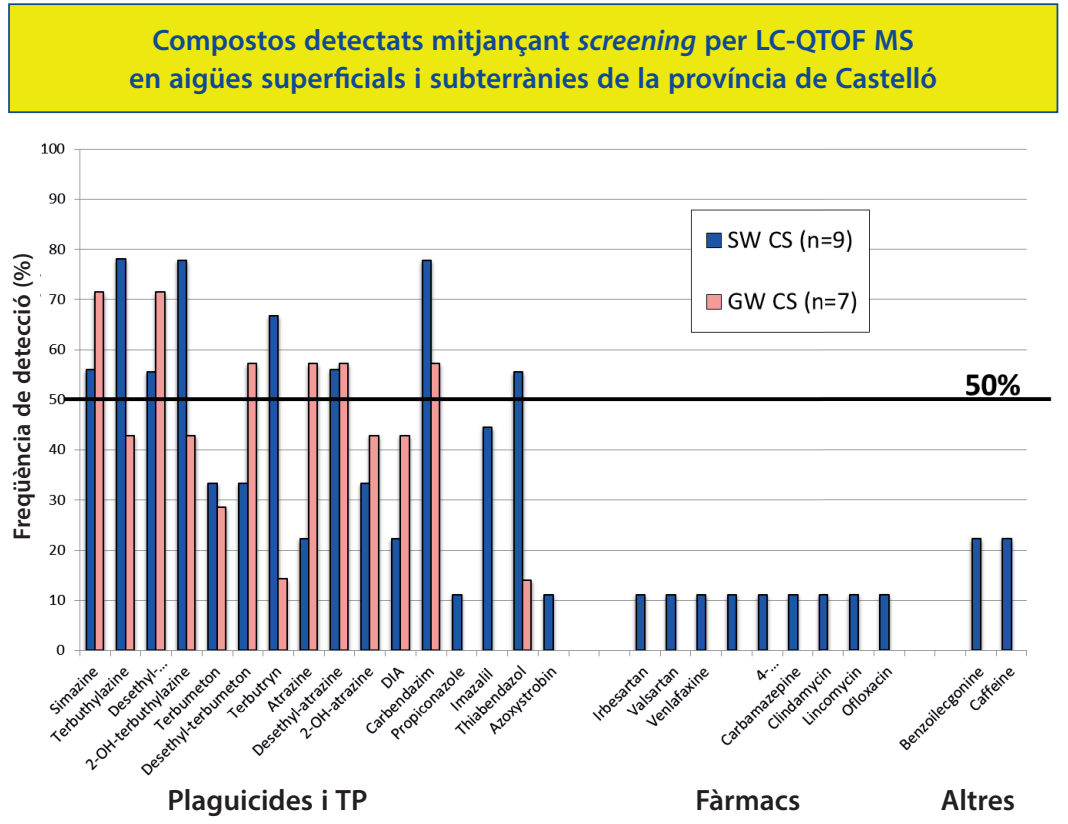

Fig. 7. Contaminants orgànics detectats en aigües superficials i subterrànies de la província de Castelló

Com podeu observar, és possible detectar drogues d'abús en les aigües. És lògic pensar que el consum de drogues conduïsca a la presència dels productes excretats, principalment, a través de l'orina (metabòlits o droga inalterada), en les aigües residuals. Les figures 8 i 9 mostren positius de MDMA (èxtasi) i de benzoïl d'ecgonina (principal metabòlit de cocaïna) en aigua residual urbana. 


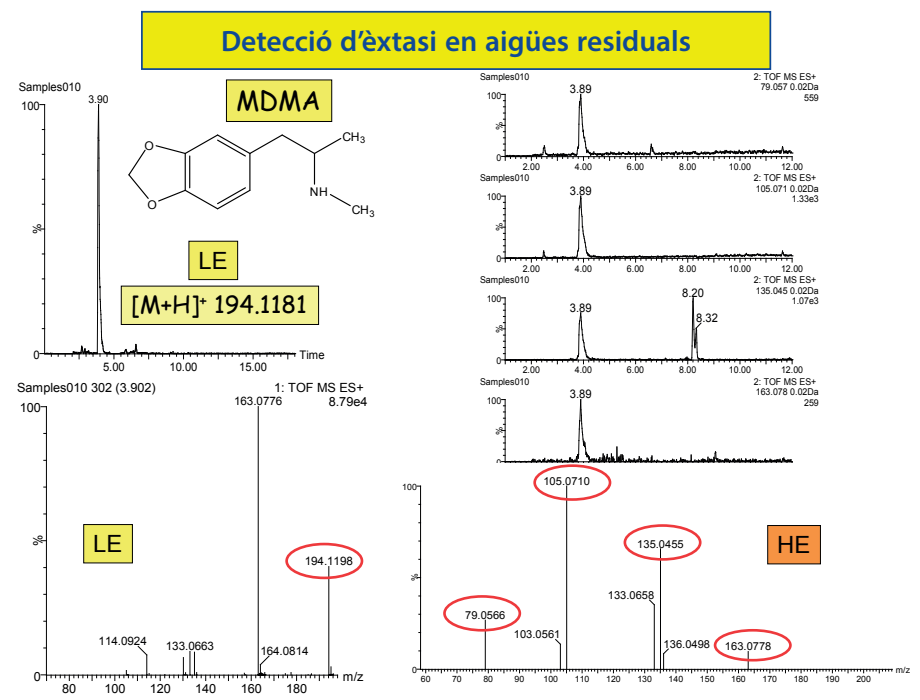

Fig. 8. Detecció de MDMA (èxtasi) per LC-QTOF MS en aigua residual urbana

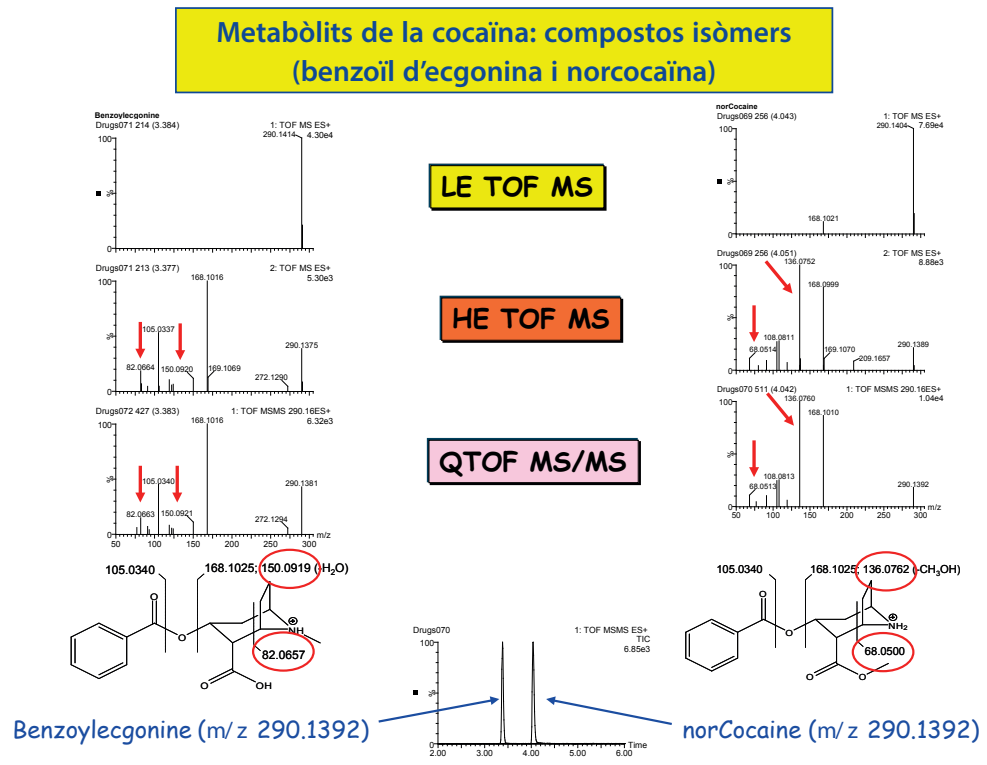

Fig. 9. Detecció dels metabòlits de la cocaïna benzoïl d'ecgonina i norcocaïna (compostos isomèrics) en aigua residual urbana 
Aquests últims exemples em porten a un aspecte que considere de rellevància. L'anàlisi d'aigües residuals a través de marcadors biològics urinaris permet estimar, de manera fiable, el consum real de drogues en una ciutat. Aquest nou enfocament, proposat per Christian G. Daughton en 2001 (Daughton, 2001), i conegut com a «anàlisi epidemiològica d'aigües residuals», ha estat possible gràcies als desenvolupaments recents de la química analítica per a la detecció de drogues d'abús en aquest tipus de mostres complicades (figura 10). A partir de la concentració del marcador biològic en l'aigua residual, i tenint en compte el metabolisme de la droga, el cabal d'aigua residual i el nombre d'habitants que aboquen les seues aigües residuals a la xarxa del sistema de tractament, es pot arribar a estimar la quantitat de droga consumida en una població (normalment en mg/ dia/1.000 habitants) (Castiglioni, 2011).

Atès que la recollida de mostres d'aigües residuals i l'anàlisi pot realitzarse diàriament, les dades es poden utilitzar per a proporcionar un índex de consum en temps real. L'EMCDDA ha reconegut aquest potencial, a través de diverses publicacions, i dóna suport a les iniciatives que es duen a terme a Europa en aquest tema (EMCDDA, 2008).

\section{The New Science of Drug Testing: The Sewers Never Lie}

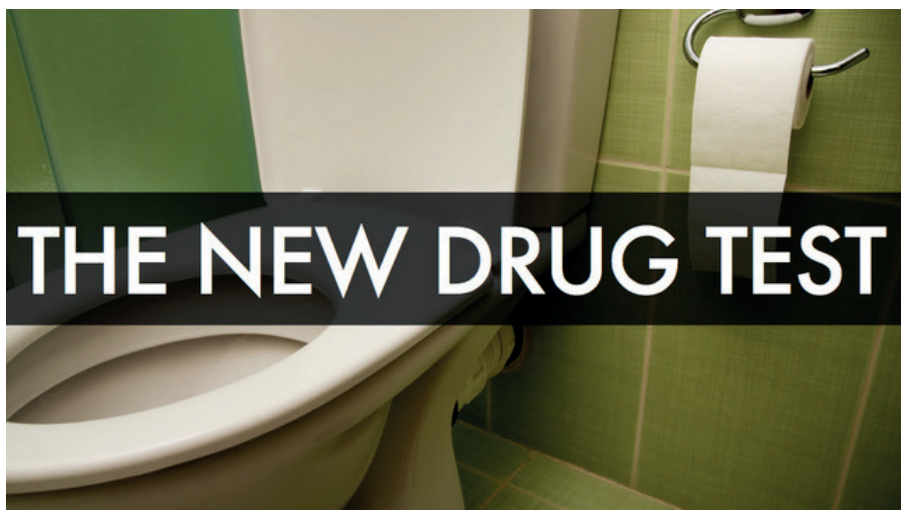

http://io9.com/5944501/toilet-tapping-how-science-is-using-sewers-to-monitor-your-drug-habit?post=52816973

Fig. 10. Epidemiologia de les aigües residuals: una eficient aproximació per a estimar el consum de drogues en una població 
En l'actualitat podem mesurar de manera ràpida canvis en els hàbits de consum en un curt període de temps. Per exemple, es pot determinar si hi ha hagut un abocament massiu de drogues a través dels desguassos dels sanitaris quan es produeixen batudes policials, i es poden observar increments en el consum de drogues els caps de setmana, o durant la celebració de festivals de música. L'augment en el consum de cocaïna en caps de setmana s'observa clarament en la figura 11, tant a través del principal metabòlit, com de la mateixa cocaïna sense metabolitzar. No obstant això, el consum de cànnabis es mostra més estable al llarg de tota la setmana, la qual cosa pareix que encaixa amb el patró de consum d'aquestes drogues.

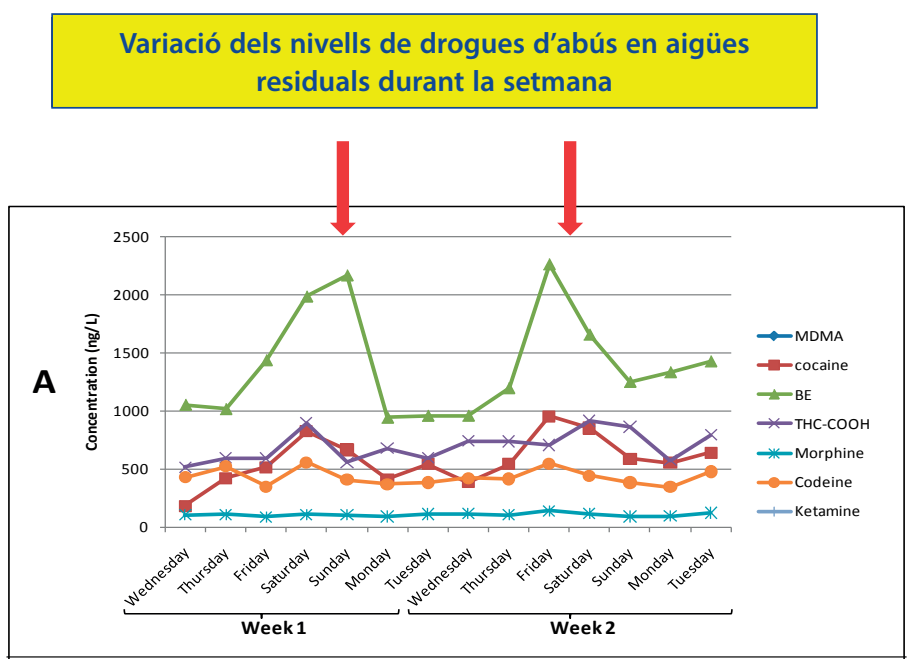

Fig. 11. Variació setmanal de la concentració de drogues detectades en aigües residuals urbanes

Per primera vegada, l'any 2011, un ampli grup de científics ha realitzat un estudi comparatiu sobre el consum de drogues d'abús (DOA) a 19 ciutats europees, basat en l'anàlisi d'aigües residuals (Thomas, 2012) (figura 12). Amb dades normalitzades segons el nombre d'habitants de cada ciutat, aquest estudi ha revelat que a les ciutats espanyoles, el consum de cànnabis i cocaïna és superior al d'altres drogues com la metamfetamina o èxtasi, i 
es troba en un nivell mitjà-alt comparat amb unes altres ciutats europees, encara que és inferior al d'Holanda i Bèlgica, per exemple (figura 13).

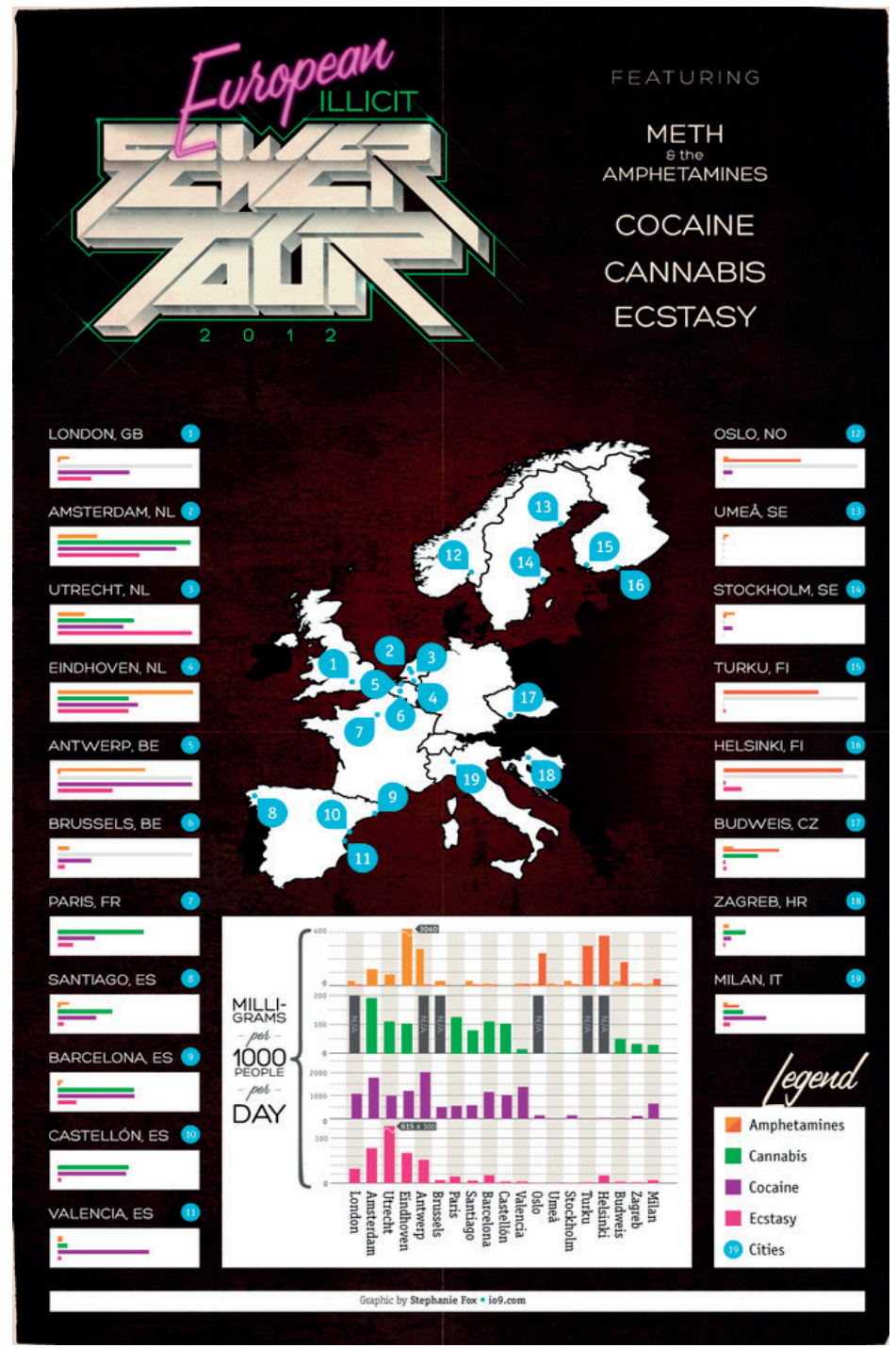

Fig. 12. Estudi comparat del consum de drogues il-lícites a 19 ciutats europees mitjançant l'anàlisi d'aigües residuals 


\section{Cocaïna (Consum en mg/dia/1.000 habitants)}

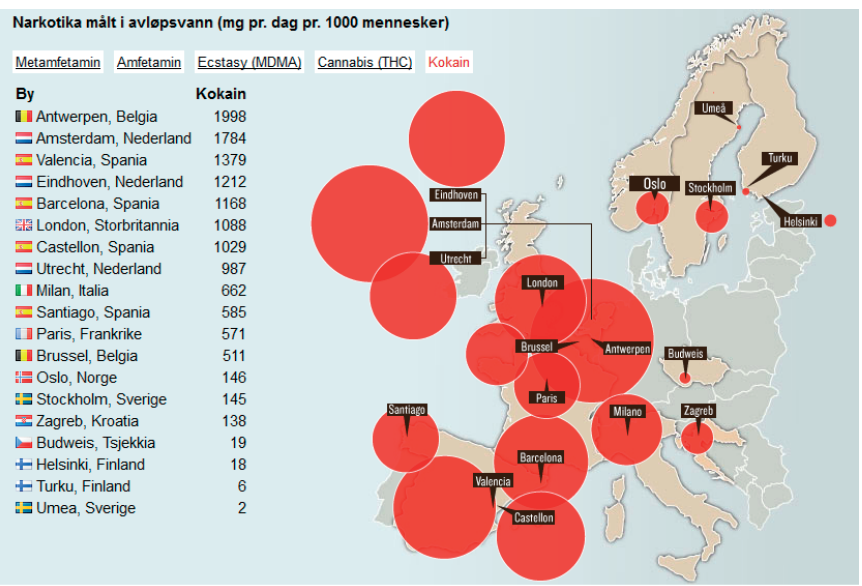

\section{Cànnabis (Consum en mg/dia/1.000 habitants)}

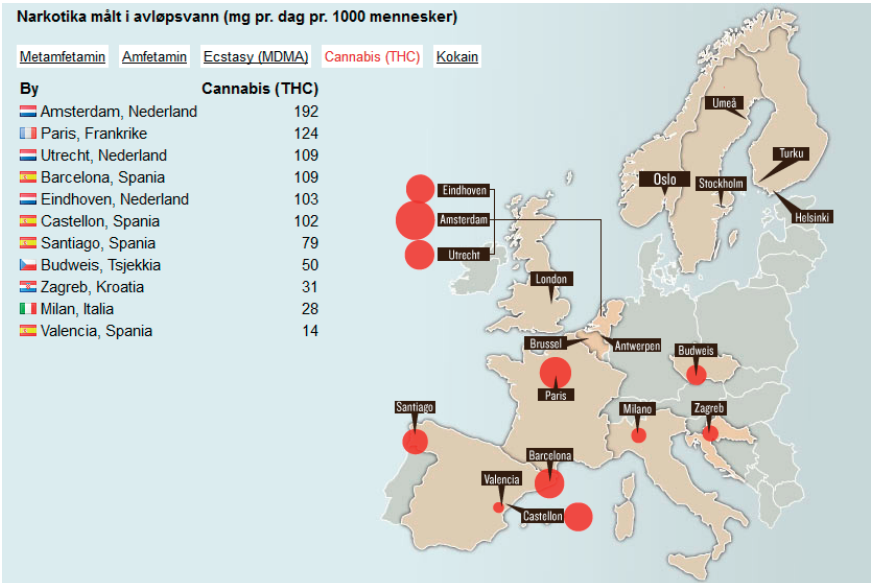

Fig. 13. Estudi comparat del consum de cocaïna i cànnabis a 19 ciutats europees mitjançant l'anàlisi d'aigües residuals

D'altra banda, el consum de cocaïna als països nòrdics pot considerarse baix, mentre que és major el de metamfetamina. De fet, el consum més gran d'aquesta droga es troba a ciutats com Oslo (Noruega), Hèlsinki i Turku 
(Finlàndia), junt amb Budweis (República Txeca). Pel que fa al MDMA (èxtasi), el consum més alt es registra a ciutats d'Holanda, com Utrecht, Eindhoven o Amsterdam (figura 14).

\section{Metamfetamina (Consum en mg/dia/1.000 habitants)}

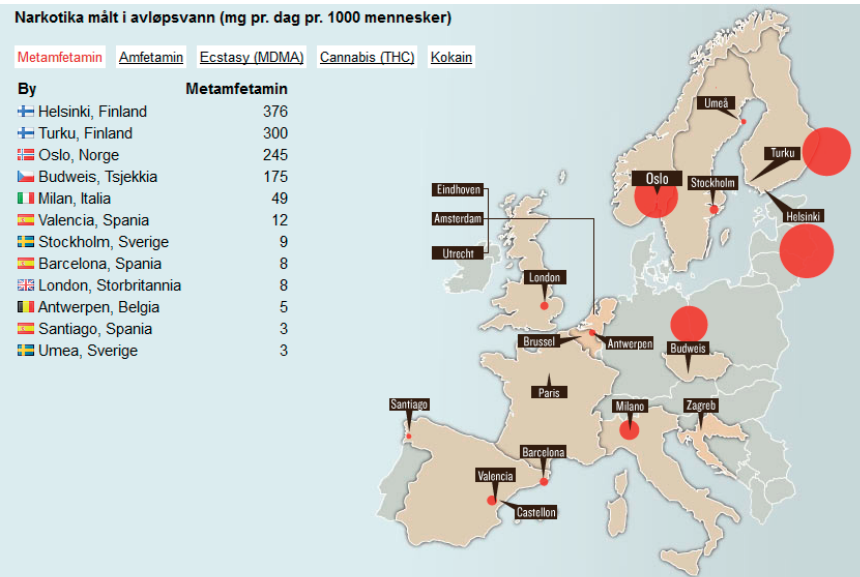

\section{Èxtasi (Consum en mg/dia/1.000 habitants)}

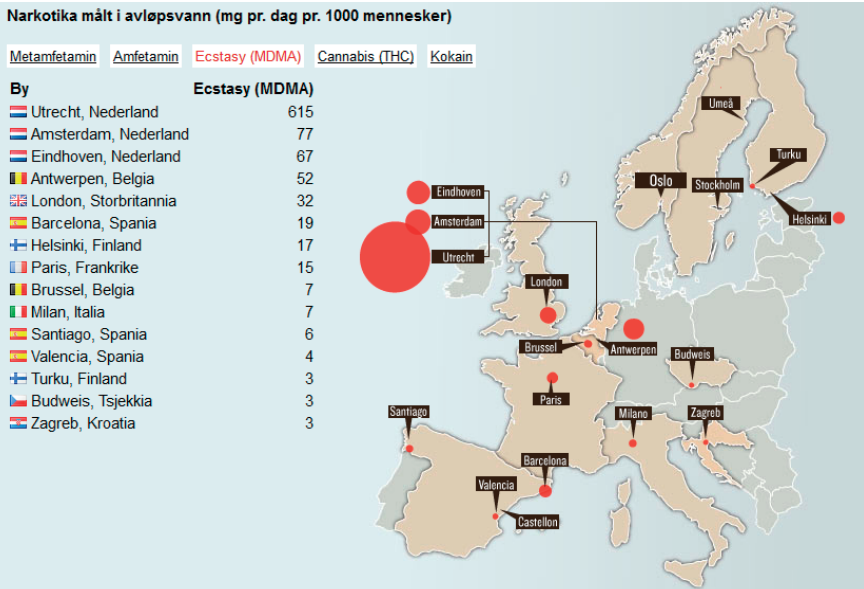

Fig. 14. Estudi comparat del consum de metamfetamina i èxtasi a 19 ciutats europees mitjançant l'anàlisi d'aigües residuals 
Però a més d'aquest enfocament, sens dubte cridaner, existeix també un vessant ambiental, perquè moltes d'aquestes drogues no són totalment eliminades en les EDAR, amb la qual cosa poden apareixen després en el medi ambient aquàtic (Bijlsma, 2012). També és cert que aquest àmbit és molt nou i que les EDAR no van ser dissenyades per a eliminar drogues que es troben a molt baixos nivells de concentració. Evidentment, això no només ocorre amb DOA, sinó també amb fàrmacs, els quals també es troben presents, com cal imaginar, en les aigües residuals.

La figura 15 mostra el grau d'eliminació de fàrmacs detectats en aigües residuals. Per a poder realitzar aquestes estimacions, és necessari determinar els nivells en les aigües d'entrada i d'eixida de la depuradora, tenint en compte el temps de residència. Es pot observar que, en general, l'eliminació de fàrmacs és satisfactòria (80-100\%), encara que hi ha alguns compostos que pareixen passar a través de l'EDAR sense patir degradació o eliminació (Gracia-Lor, 2012). Davant d'aquesta situació, coneguda des de fa tan sols uns pocs anys, les EDAR implanten ara sistemes addicionals de tractament - per exemple d'oxidació avançada, radiació UV, fotodegradació- per a millorar aquest aspecte. Sens dubte, això obliga a realitzar fortes inversions, així com esforços afegits en períodes que coincideixen amb grans esdeveniments o festivitats.

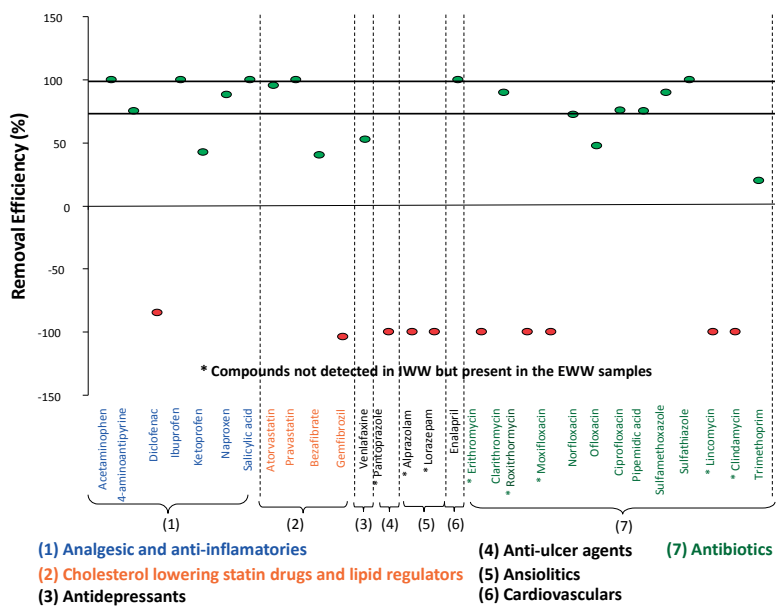

Fig. 15. Eliminació de fàrmacs en una planta de tractament d'aigües residuals urbanes (EDAR) 


\section{SEGURETAT ALIMENTÀRIA}

Si el medi ambient és fonamental per a la nostra qualitat de vida, la seguretat alimentària no ho és menys. Evidentment, volem que els aliments que consumim tinguen una qualitat adequada, per a la qual cosa és imprescindible que estiguen Iliures de contaminants i residus tòxics, o que, almenys, els nivells siguen acceptables d'acord amb l'estat actual del coneixement.

Molts problemes de seguretat alimentària tenen l'origen en agents biològics (ex.: presència de la salmonel.la en aliments). No em referiré a aquest tipus de riscos biològics, sinó als perills químics de la cadena alimentària (figura16):

- En els aliments es poden trobar contaminants d'origen ambiental, com ara metalls i compostos orgànics persistents, entre els quals es troben les ja mencionades dioxines.

- Residus de medicaments d'ús veterinari. Per exemple, antibiòtics o agonistes beta, com el clenbuterol, anabolitzant usat de manera fraudulenta per a l'engreixament del bestiar, ja que promou el creixement muscular i inhibeix l'acumulació de greix en el cos.

- La presència de residus de plaguicides en concentracions superiors al límit màxim de residus (LMR) legalment establit és un clàssic en seguretat alimentària per l'àmplia utilització d'aquests compostos. La causa més freqüent d'aquests incompliments sol trobar-se en una mala pràctica agrícola, com l'aplicació de dosis superiors a les recomanades o l'incompliment dels terminis de seguretat entre aplicació del plaguicida i recollida del producte al camp. També s'ha reportat la presència de plaguicides no autoritzats, la qual cosa constitueix un frau que, de vegades, és fruit d'un error a l'haver usat plaguicides no registrats per a un cert cultiu, encara que no obstant això puguen estar autoritzats per a molts altres.

- Compostos tòxics derivats del processament d'aliments (generalment processos tèrmics), com l'acrilamida, o del contacte amb els envasos d'aliments, com el bisfenol A, són també casos significatius.

- Substàncies prohibides o no autoritzades, com ara colorants illegals de la família del Sudan, que són colorants industrials que normalment s'utilitzen per a tenyir plàstics i altres materials sintètics, però prohibits en aliments. O la melamina, afegida de manera fraudulenta a pinsos 


\section{i productes lactis, incloent-hi aliments infantils, per a augmentar de manera aparent el contingut proteic.}

\section{Contaminants químics rellevants en aliments (I)}

\begin{tabular}{|l|l|}
\hline Contaminant químic & Observacions \\
\hline $\begin{array}{l}\text { Contaminants d'origen } \\
\text { ambiental }\end{array}$ & $\begin{array}{l}\text { Metalls (As, Cd, Hg, Cr, Pb, etc.). } \\
\text { Compostos orgànics persistents (dioxines, PCB, PBDE, etc.). }\end{array}$ \\
\hline $\begin{array}{l}\text { Residus farmacològics } \\
\text { i fitosanitaris }\end{array}$ & $\begin{array}{l}\text { Medicaments d'ús veterinari (no autoritzats): antibiòtics, clenbuterol, etc. } \\
\text { Plaguicides (herbicides, insecticides, fungicides), de diversa composició química i LMR. }\end{array}$ \\
\hline $\begin{array}{l}\text { Compostos tòxics } \\
\text { derivats } \\
\text { del processament } \\
\text { d'aliments }\end{array}$ & $\begin{array}{l}\text { Acids grassos trans (AGT), transformació d'olis líquids en sòlids (margarines). } \\
\text { Furan, format en el tractament tèrmic d'aliments (cafè, sopes, aliments infantils). } \\
\text { Hidrocarburs policíclics aromàtics (PAH) en aliments a la planxa, barbacoa, fumats. } \\
\text { Acrilamida, aliments fregits rics en carbohidrats (patates fregides). }\end{array}$ \\
\hline $\begin{array}{l}\text { Compostos tòxics } \\
\text { derivats de materials } \\
\text { en contacte } \\
\text { amb els aliments }\end{array}$ & $\begin{array}{l}\text { Semicarbazida. Per degradació tèrmica d'azidocarbonamida, un additiu expansor utilitzat en } \\
\text { les juntes de plàstic. } \\
\text { 2-isopropiltioxantona (ITX), component de la tinta emprada en tècniques d'impressió del } \\
\text { material d'embalatge del sistema d'envasament. } \\
\text { Bisfenol A, forma part del policarbonat plàstic utilitzat en la fabricació d'envasaments per a } \\
\text { aliments i begudes (incloent-hi biberons i vaixella) i el recobriment interior de contenidors } \\
\text { d'aliments. } \\
\text { 4-metil-benzofenona i benzofenona, en tintes flexogràfiques UV i laques per a impres- } \\
\text { sió aplicades en superfície d'embalatges, principalment caixes de cartró. Poden migrar a } \\
\text { l'envasament i contaminar productes alimentaris fins i tot sòlids (cereals per al desdejuni). }\end{array}$ \\
\hline
\end{tabular}

\section{Contaminants químics rellevants en aliments (II)}

\begin{tabular}{|l|l|}
\hline Contaminant químic & Observacions \\
\hline $\begin{array}{l}\text { Substàncies prohibides o } \\
\text { no autoritzades }\end{array}$ & $\begin{array}{l}\text { Colorants il-legals, com ara Sudan I, II, III i IV, colorants industrials que normalment s'utilitzen } \\
\text { per a tintar plàstics i uns altres materials sintètics, però prohibits en aliments. } \\
\text { Melamina en pinsos, productes lactis i aliments infantils, afegida fraudulentament per a aug- } \\
\text { mentar el contingut proteic aparent. }\end{array}$ \\
\hline Micotoxines & $\begin{array}{l}\text { Toxines produïdes per fongs que contaminen aliments (fruits secs, cereals, fruita dessecada, } \\
\text { cafè, espècies, etc.) } \\
\text { Aflatoxines, les que millor es coneixen. Se'n troben als cacauets, dacsa, fruits secs i algunes } \\
\text { fruites com les figues. Els pinsos contaminats per aflatoxines constitueixen un problema de } \\
\text { seguretat alimentària atès que poden acumular-se en els animals destinats a produir aliments. } \\
\text { De particular importància les vaques lleteres, les quals poden excretar aflatoxines per la llet. } \\
\text { Ocratoxina A (productes vegetals com ara cereals, grans de cafè, cacau i fruites dessecades). } \\
\text { Patulina (derivats de la poma). Toxines de Fusarium: deoxinivalenol i zearalenona (en diversos } \\
\text { aliments). }\end{array}$ \\
\hline Biotoxines marines & $\begin{array}{l}\text { Associades a les marees roges. Algues dinoflagel-lades que originen intoxicacions agudes com } \\
\text { a conseqüència del consum de peixos o mol-luscs filtradors (cloïsses, musclos, ostres, vieires, } \\
\text { etc.) els quals s'alimenten d'algues i acumulen les toxines. } \\
\text { Acid okadaic, domoic, azaspiràcides, palitoxines, etc. }\end{array}$ \\
\hline Tòxics naturals & $\begin{array}{l}\text { Bolets. } \\
\text { Radionucleids }\end{array}$ \\
\hline $\begin{array}{l}\text { Els aliments poden contenir radioactivitat de manera natural i/o estar contaminats amb mate- } \\
\text { rials radioactius com a resultat de fuites accidentals per incidents nuclears o radiològics. }\end{array}$ \\
\hline
\end{tabular}

Fig. 16. Principals contaminants químics en aliments 
- En certes situacions no hi ha una adulteració o utilització intencionada de productes prohibits, però també hi ha un risc per a la salut per la presència de productes tòxics. És el cas de les micotoxines, produïdes per diversos centenars d'espècies de fongs que poden créixer en els aliments en determinades condicions. Se solen trobar en fruites seques, cereals, o cafè, entre altres aliments. Poden aparèixer també com a conseqüència d'un emmagatzemament en males condicions. En refrigeració, no només el creixement fúngic és menor, sinó també la producció proporcional de micotoxines. Les intoxicacions greus produïdes per aquestes toxines «naturals» ja es van reportar fa segles, encara que es desconeixia la causa. "Hi havia al carrer homes que es desplomaven, entre crits i contorsions; altres queien i tiraven bromera per la boca, afectats per crisis epilèptiques, i alguns vomitaven i donaven signes de bogeria. Molts cridaven: "Foc! M'abrase!". Es tractava d'un foc invisible que desprenia la carn dels ossos i la consumia. Homes, dones i xiquets agonitzaven amb dolors insuportables». Aquestes van ser les paraules que va utilitzar un cronista del segle $X$ per a descriure una malaltia que afectava nombrosos països d'Europa. La malaltia es va conèixer com el «foc de Sant Antoni» a causa de la sensació abrasadora experimentada per les víctimes, moltes de les quals visitaven el santuari de Sant Antoni, a França, amb l'esperança de curar-se. Sabem ara que el «foc de Sant Antoni» (ergotisme) es devia al consum de sègol contaminat amb alcaloides ergòtics, produïts pel fong Claviceps purpurea o banya del sègol, que va aconseguir proporcions epidèmiques a moltes bandes d'Europa en el segle $X$.

- Un altre problema important de salut pública són les intoxicacions produïdes per toxines marines, coincidint amb episodis de marees roges d'algues dinoflagel-lades. Aquestes intoxicacions són causades pel consum de mol.luscos filtrants que s'alimenten d'aquestes algues i que acumulen toxines perilloses, com l'àcid okadaic o domoic, entre altres.

Davant d'aquestes situacions es requereix una resposta ràpida dels organismes de control. Però, de nou, es treballa sobre llistats prioritaris perquè no existeixen mètodes universals d'anàlisi. Són necessàries, per tant, investigacions avançades per a afrontar aquests o uns altres problemes que puguen aparèixer. A tal fi, és fonamental la col-laboració entre laboratoris 
de salut pública i centres d'investigació d'universitats o del CSIC (per cert, abans que faça fallida o el desmantellen), de manera que els laboratoris de control realitzen les anàlisis de rutina, mentre els grups d'investigació en química analítica avancen en el desenvolupament de noves metodologies.

Igual que en l'àmbit del medi ambient, la QA té al davant un dels reptes més importants: ser capaç de donar una resposta ràpida, d'acord amb les circumstàncies actuals i a les demandes de la societat. Una vegada més, hem de treballar amb acoblaments cromatografia/MS, s'hi poden usar estratègies semblants a les mediambientals (Caprioli, 2012; Wang, 2009; Picó, 2008). Normalment, s'apliquen mètodes target per separat per a cada família de compostos, encara que la tendència és cap a l'aplicació de mètodes més amplis, capaços de detectar, identificar i quantificar diversos tipus de contaminants (ex.: micotoxines, plaguicides, fàrmacs d'ús veterinari, etc.) en una única anàlisi.

La figura 17 il.lustra la detecció de residus de plaguicides en una mostra de nectarina. Amb una anàlisi realitzada amb GC-MS/MS és possible detectar, identificar i quantificar simultàniament diversos plaguicides (tres organofosforats i una piretrina) a escales de concentració inferiors a 0,03 $\mathrm{mg} / \mathrm{kg}$ en tots els casos (Cervera, 2010). La determinació de residus de plaguicides constitueix una àrea prioritària en els laboratoris de salut pública. Existeix extensa i detallada regulació sobre la presència d'aquests compostos i l'anàlisi en aliments (Regulation EC 396/2005; García-Reyes, 2007; Mol, 2012).

En la investigació de fàrmacs/drogues d'ús veterinari en productes carnis sol ser habitual no trobar-hi a penes casos positius, fins quan s'analitza un nombre elevat de mostres. Açò, sens dubte, és una bona notícia, però a pesar d'això, hi ha una certa preocupació perquè en els mètodes analítics de control s'inclou tan sols un nombre limitat de compostos -els regulats o els que més preocupen - per la qual cosa, altres fàrmacs, que podrien usarse de manera fraudulenta, no els detectarien les anàlisis. Davant d'aquesta situació, que típicament també s'ha donat en l'entorn del dopatge en l'esport, la resposta de la QA es troba en els mètodes d'escombratge d'ampli rang. Actualment, es poden aplicar metodologies de screening per a fàrmacs d'ús veterinari i humà en pinsos per al bestiar, aquests mètodes també es poden ampliar a l'aigua de beguda i, amb certes modificacions, a les mostres de 
carn. Aquestes tècniques, capaces d'investigar centenars de fàrmacs, permeten alertar sobre la presència de compostos no esperats, que, una vegada detectats, passarien a formar part dels mètodes quantitatius de rutina.

\section{Detecció de residus de plaguicides en nectarina mitjançant GC-MS/MS}
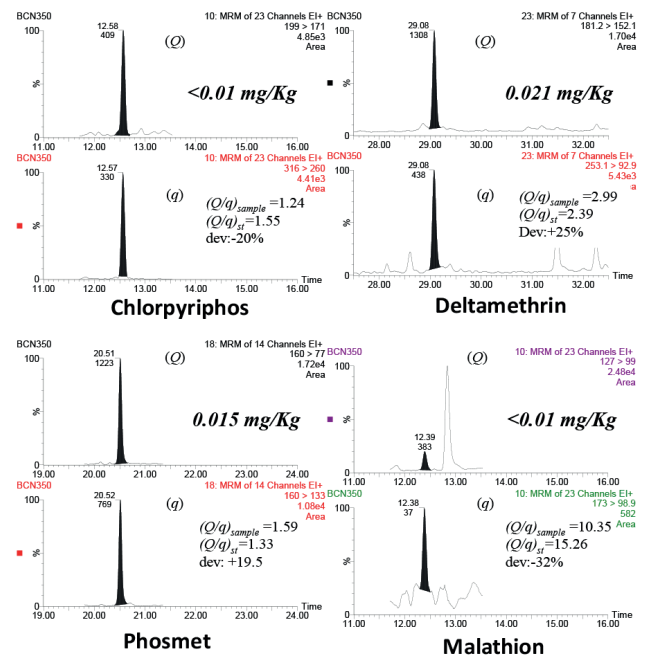

Fig. 17. Detecció de residus de plaguicides organofosforats i deltametrina en nectarina mitjançant GC-MS/MS amb triple quadrupol

La figura 18 mostra la detecció de micotoxines en dacsa. Amb la metodologia analítica aplicada s'hi poden detectar de manera simultània diverses micotoxines a escales de concentració de ppb en dues mostres de dacsa. Encara que una mateixa mostra conté fins a quatre micotoxines, en cap d'aquestes se superen els límits màxims permesos.

En relació amb les micotoxines, m'agradaria mencionar una interessant iniciativa duta a terme recentment per la Conselleria de Sanitat. Es tracta d'un estudi sobre la dieta total (EDT) a la Comunitat Valenciana, que consisteix a seleccionar, mostrejar i analitzar els aliments de consum generalitzat de la població objecte d'estudi. En un EDT s'intenta reproduir les pràctiques habituals dels consumidors i consumidores. Els aliments se solen adquirir en establiments detallistes i es preparen del mode en què es consumeix cada 
un d'aquests, incloent-hi el cuinat, si cal, i d'acord amb els hàbits alimentaris característics de la població estudiada.

Un EDT ha de ser representatiu del consum de la població, per la qual cosa un pas fonamental és definir els aliments que constitueixen la dieta mitjana de la població. Aquesta informació s'aconsegueix amb d'enquestes de consum. A més a més, se sol afegir-hi aliments que, si bé es consumeixen en quantitats baixes, tenen interès especial pel tipus de substància susceptible d'aparèixer. En aquest cas es trobarien els fruits secs, pel contingut que tenen en micotoxines, o els mol.luscos i crustacis, pel contingut en metalls pesants. Aquest tipus d'estudis duen una càrrega analítica molt important, perquè es requereix l'anàlisi de nombrosos contaminants a escales de concentració el més baix possible, per la qual cosa són necessaris mètodes analítics sofisticats.

En l'estudi realitzat a la Comunitat Valenciana es van analitzar en els aliments contaminants com ara metalls pesants, micotoxines, dioxines $\mathrm{i}$ hidrocarburs policíclics aromàtics (PAH). No s'hi van incloure plaguicides perquè ja es disposa d'àmplia informació, gràcies als programes de residus en aliments, que s'apliquen en el territori nacional des de fa diversos anys.

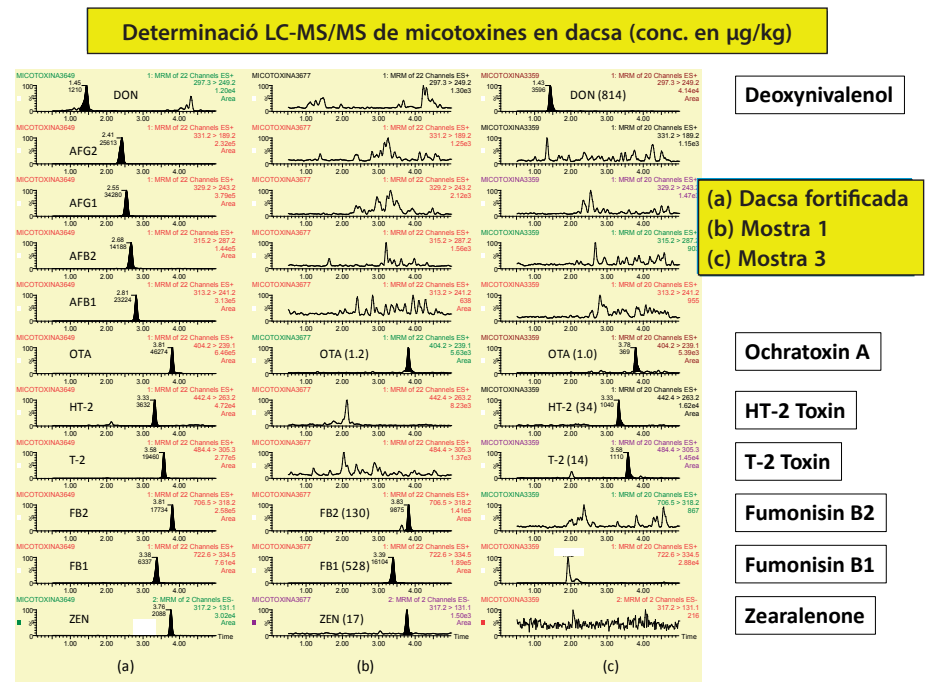

Fig. 18. Detecció de micotoxines en dues mostres de dacsa mitjançant l'anàlisi realitzada per LC-MS/MS amb triple quadrupol 


\section{REFLEXIÓ FINAL}

Encara que no es tracta d'un problema de seguretat alimentària ni de contaminació ambiental, voldria acabar aquesta exposició amb un cas que em pareix rellevant i que, sens dubte, suposa un greu problema de salut pública. Em referisc a la investigació sobre drogues de síntesi, conegudes també com a legal highs o research chemicals, en productes que poden adquirir-se lliurement en certes botigues i en Internet. Es tracta d'herbes, pastilles, pols, que contenen compostos menys coneguts que les drogues il.legals, però que poden causar estralls, especialment en la joventut. Són productes que, sota l'eslògan «No aptes per al consum», es vénen «només per a col-leccionistes», però amb etiquetes i il.lustracions que fan dubtar de la verdadera finalitat (figura 19). En general, no tenen regulació i poden adquirir-se sense excessius problemes.

Sobres d'herbes que contenen cannabinoides sintètics JWH
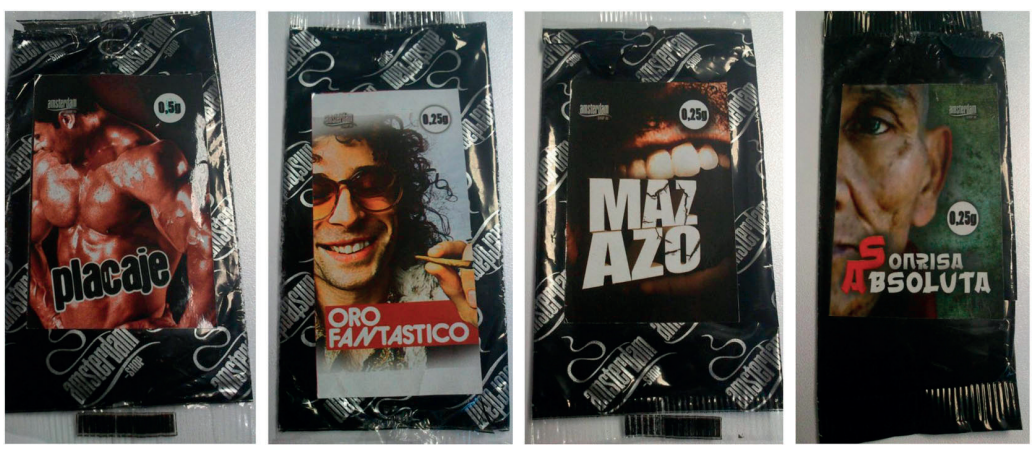

Fig. 19. Sobres d'herbes (herbal blends) l'anàlisi dels quals per mitjà de LC-QTOF MS demostra la presència de cannabinoides sintètics JWH

Recentment hem investigat la composició d'uns sobres d'herbes adquirits en smart shops, els quals també es poden adquirir fàcilment en Internet. Després de realitzar un screening d'uns 200 compostos candidats, seleccionats a la llum de la bibliografia existent, detectem en aquestes herbes diversos 
cannabinoides sintètics, de la sèrie JWH, que havien estat afegits de manera intencionada a les mateixes (Ibáñez, 2013). Aquest grup de compostos va ser sintetitzat en la dècada dels 80 per John William Huffman, de Clemson University, amb fins mèdics, per a ajudar en el tractament de l'esclerosi múltiple, de la sida o dels efectes secundaris de la quimioteràpia.

En 2008 dos d'aquests compostos van començar a vendre's a Alemanya com a alternatives a la marihuana, encara que ja es venien com a encens a uns quants països des de 2002. "Ja vaig imaginar que una vegada es va iniciar la venda a Alemanya, el procés s'estendria en altres països. Estic molt preocupat perquè açò pot causar problemes a la gent», va afirmar Huffman. "Pense que açò era quelcom, en certa manera, inevitable. Em preocupa que la gent siga tan estúpida com per a usar aquests productes per al seu consum». Huffman havia desenvolupat aquests compostos per a investigació científica, però ara se sentia en certa manera culpable per l'abús que se'n feia. El compost inicialment usat com a alternativa a la marihuana era el JWH-018, potent i fàcil de sintetitzar (figura 20).

\section{CLEMSON UNIVERSITY \\ Department of Chemistry}

John W. Huffman

Research Professor

Organic Chemistry

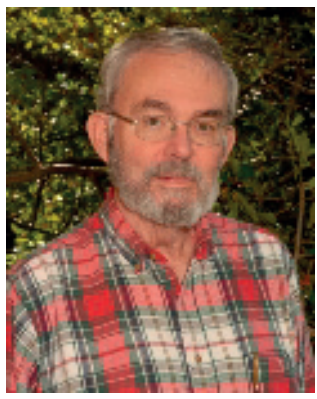

\section{Síntesi de 450 cannabinoides} sintètics (JWH)

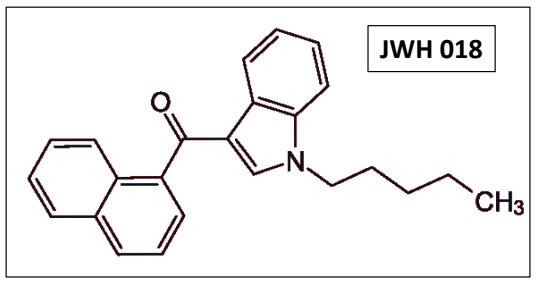

"I figured once it got started in Germany it was going to spread. I'm concerned that it could hurt people," Huffman said. "I think this was something that was more or less inevitable. It bothers me that people are so stupid as to use this stuff".

Fig .20. El professor John W. Huffman, qui per primera vegada va obtenir cannabinoides sintètics (450), coneguts des de llavors com JWH. 
De llavors ençà, la composició d'aquest tipus d'herbes s'ha modificat al llarg del temps. La prohibició del JWH-018 va portar a l'aparició d'altres cannabinoides sintètics, com JWH-073, JWH-081, o JWH-250, els quals es diferencien dels predecessors per la localització dels grups químics substituents, o per l'addició de grups metil, etil o metoxil.

A l'afegir aquests compostos de síntesi a les herbes es pretén simular l'acció del cànnabis, però poden arribar a resultar més perillosos. Possiblement, el consumidor assumeix que es tracta d'herbes naturals i, sota la falsa creença que com que és un producte natural no pot ser molt perjudicial, el consumeix (normalment fumat) sense massa precaucions. Doncs bé, en alguns d'aquests sobres trobem fins a quatre cannabinoides sintètics. El compost JWH-081 es va detectar en tots els sobres analitzats, bé tot sol o combinat amb altres compostos de la sèrie, com el JWH-250, JWH-203 o JWH-019 (figura 21).

\begin{tabular}{|c|c|c|}
\hline $\begin{array}{l}\text { Type of } \\
\text { sample }\end{array}$ & Product name & $\begin{array}{l}\text { Identified } \\
\text { compound }\end{array}$ \\
\hline \multirow{6}{*}{ 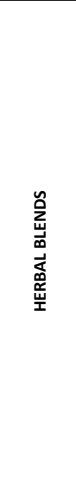 } & ORO FANTÁSTICO & JWH-081 \\
\hline & SONRISA ABSOLUTA & $\begin{array}{l}\text { JWH-081 } \\
\text { JWH-250 }\end{array}$ \\
\hline & PLACAJE/1 & $\begin{array}{l}\text { JWH-081 } \\
\text { JWH-250 } \\
\text { JWH-019 } \\
\text { JWH-203 }\end{array}$ \\
\hline & PLACAJE/2 & $\begin{array}{l}\text { JWH-081 } \\
\text { JWH-250 }\end{array}$ \\
\hline & MAZAZO/1 & $\begin{array}{l}\text { JWH-081 } \\
\text { JWH-250 } \\
\text { JWH-019 } \\
\text { JWH-203 }\end{array}$ \\
\hline & MAZAZO/2 & $\begin{array}{l}\text { JWH-081 } \\
\text { JWH-250 } \\
\text { JWH-019 } \\
\text { JWH-203 }\end{array}$ \\
\hline
\end{tabular}

Fig. 21. Resultats d'anàlisi realitzada per mitjà de LC-QTOF MS en mostres $\mathrm{d}$ 'herbes (herbal blends), la qual mostra la presència de cannabinoides sintètics

Les dades disponibles en bibliografia sobre els possibles efectes negatius per a la salut són preocupants. I, pitjor encara, l'efecte sinèrgic que pot pro- 
duir una mescla de diversos JWH és poc conegut, encara que s'han descrit pacients amb símptomes psicòtics i catatònics que podrien explicar-se pel consum i posterior acció d'aquests compostos.

Anàlisis addicionals de productes adquirits en Internet (figura 22) han demostrat la presència generalitzada de catinones en pols i pastilles. Es tracta de compostos sintètics derivats de la catinona, principi actiu de la planta del cat, l'estructura química de la qual està relacionada amb l'amfetamina. En les mostres analitzades detectem fins a set catinones diferents. Les pols contenien generalment una sola catinona, amb l'excepció de Gran Misteri, mentre que les pastilles contenien mescles de dos a tres compostos (figura 23).

La catinona més sovint detectada va ser 3,4-metiledioxipirovalerona (MDPV), a la qual se li han atribuït efectes estimulants semblants a les amfetamines. Aquesta droga de disseny es va detectar sola o combinada amb altres catinones, com la butilona (bk-MBDB), metilonaomethedrona (4-metoximetcatinona). Aquesta última, notificada per primera vegada pels sistemes d'alerta precoç (Early Warning System) a l'octubre del 2009, es va associar a dues morts ocorregudes a Suècia.
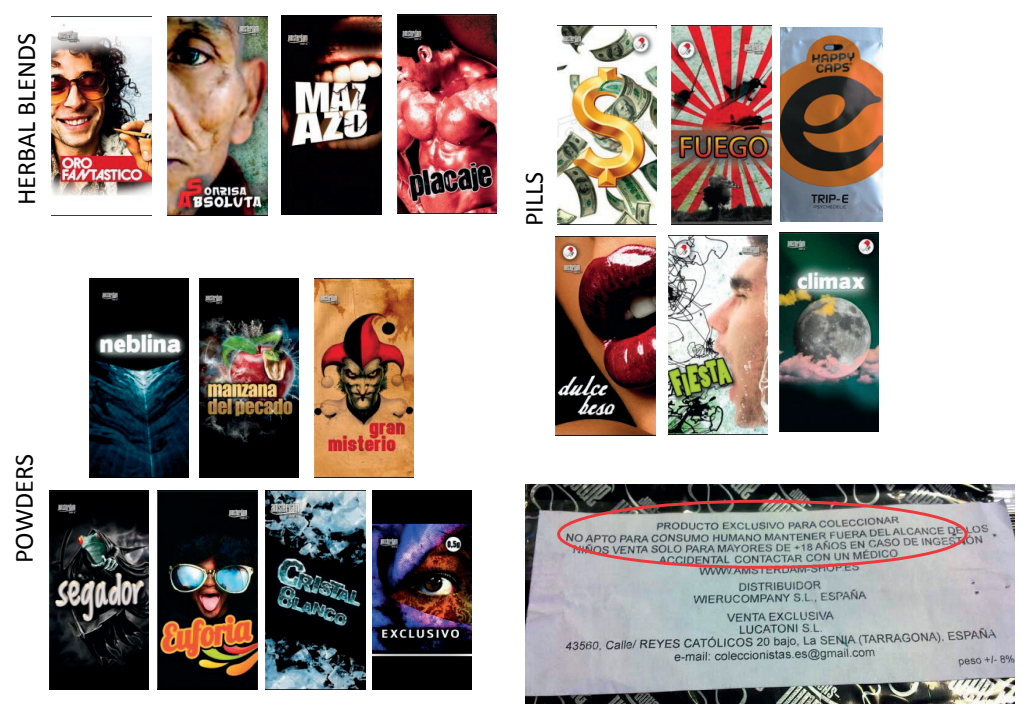

Fig. 22. Embalatges de diversos productes que contenen drogues de disseny (legal highs), principalment cannabinoides sintètics i catinones 
Pastilles (Trip-e) que contenen l'amida de l'àcid lisèrgic (LSA), un alcaloide de la família de les ergolines. Solucions bevibles amb metilona (green extract) i 4-fluoroamfetamina (blue extract). O trufes amb psilocina, alcaloide derivat de la triptamina present en la majoria de fongs al-lucinògens, són altres exemples de mostres analitzades.

\begin{tabular}{|c|c|c|}
\hline & Anàlisi de p & stilles \\
\hline $\begin{array}{l}\text { Type of } \\
\text { sample }\end{array}$ & Product name & $\begin{array}{l}\text { Identified } \\
\text { compound }\end{array}$ \\
\hline \multirow{7}{*}{$\stackrel{n}{\vec{a}}$} & DULCE BESO & $\begin{array}{c}\text { METHEDRONE } \\
\text { METHYLONE }\end{array}$ \\
\hline & FUEGO & $\begin{array}{l}\text { METHYLONE } \\
\text { MDPV }\end{array}$ \\
\hline & CLIMAX & $\begin{array}{c}\text { BUTHYLONE } \\
\text { MDPV } \\
\text { NAPHYRONE }\end{array}$ \\
\hline & FIESTA & $\begin{array}{c}\text { METHEDRONE } \\
\text { MDPV }\end{array}$ \\
\hline & $\$$ & $\begin{array}{c}\text { MDPV } \\
\text { ETHCATHINONE } \\
\text { BUTYLONE }\end{array}$ \\
\hline & EXCLUSIVO & $\begin{array}{c}\text { BUTYLONE } \\
\text { MDPV }\end{array}$ \\
\hline & TRIP-e & $\begin{array}{c}\text { CAFFEINE } \\
\text { NICOTINAMIDE } \\
\text { TRIPTOPHAN } \\
\text { LSA (NATURAL) }\end{array}$ \\
\hline
\end{tabular}

\begin{tabular}{|c|c|c|}
\hline & \multicolumn{2}{|c|}{ Altres productes } \\
\hline $\begin{array}{l}\text { Type of } \\
\text { sample }\end{array}$ & Product name & $\begin{array}{l}\text { Identified } \\
\text { compound }\end{array}$ \\
\hline \multirow{6}{*}{ 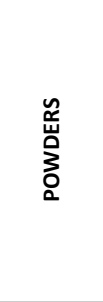 } & SEGADOR & MDPV \\
\hline & EUFORIA & BUTYLONE \\
\hline & GRAN MISTERIO & $\begin{array}{c}\text { BUTYLONE } \\
\text { MDPV }\end{array}$ \\
\hline & CRISTAL BLANCO & ETHCATHINONE \\
\hline & NEBLINA & METHYLONE \\
\hline & $\begin{array}{c}\text { MANZANA DEL } \\
\text { PECADO } \\
\end{array}$ & 4'-MePPP \\
\hline \multirow[t]{2}{*}{ LIQUIDS } & BLUE EXTRACT & $\begin{array}{c}\text { 4-FLUORO } \\
\text { AMPHETAMINE }\end{array}$ \\
\hline & GREEN EXTRACT & METHYLONE \\
\hline TRUFFLES & $\begin{array}{l}\text { PSILOCYBE } \\
\text { ATLANTIS } \\
\text { TRUFFLES }\end{array}$ & PSILOCIN \\
\hline
\end{tabular}

Fig. 23. Resultats d'una anàlisi realitzada per mitjà de LC-QTOF MS a pastilles, pols, solucions bevibles i trufes, la qual mostra la presència de diverses drogues de disseny, principalment catinones

La quantitat i varietat de drogues de síntesi en l'actualitat són realment preocupants. Drogues de qualsevol tipus, amb greus efectes sobre la salut, circulen sense a penes control. A banda de moltes altres mesures, de tipus social, educatiu o policial, la QA pot alertar sobre l'existència d'aquestes o unes altres de drogues noves. De vegades són conegudes però, davant de la possibilitat que es tracte de derivats d'altres drogues a les quals se'ls realitzen modificacions químiques en l'estructura, resulten de poca utilitat els mètodes convencionals d'anàlisi. No obstant això, fent ús de HRMS es poden aplicar estratègies útils com són la detecció i identificació temptativa 
de llarguíssimes llistes de candidats, la cerca de fragments comuns amb altres drogues ja reportades, o l'anàlisi retrospectiva, ja que una vegada realitzades les anàlisis, es disposa de l'espectre complet en massa exacta, és possible una revisió de les dades en qualsevol moment, fins i tot anys després, per a investigar la presència de compostos que en el passat no es van buscar, sense necessitat realitzar noves anàlisis.

Per a acabar voldria ressaltar alguns valors que, en la meua opinió, són fonamentals per a l'avanç del coneixement, bé en l'àmbit que hem abordat avui, o bé en qualsevol altre àmbit de la ciència.

Res del que ací s'ha indicat es pot aconseguir sense esforç, sense entrega, sense il.lusió; jo diria inclús, sense passió. Avui li ha correspost el protagonisme a la química analítica, però demà li correspondrà a unes altres àrees del coneixement. Parlem ara de recerca, però podríem també aplicar aquests mateixos valors a molts altres aspectes de les nostres vides. Lamentablement, no pareixen ser valors en alça, sinó més aviat tot al contrari. Per això, resulta necessari inculcar, especialment en les persones més joves, que seran els amos del futur pròxim, el valor de l'esforç, perquè res que pague realment la pena, res del que podem sentir-nos orgullosos, es pot aconseguir sense esforç!

No només els investigadors sèniors, com jo, sinó els més joves, els estudiants i les estudiantes universitaris, tots nosaltres, hem de lluitar pel que creiem; treballar amb el ferm convenciment que podem ajudar a millorar les coses, a modificar allò que no ens agrada. Les prioritats personals, institucionals i polítiques, es poden modificar, es poden modelar. És possible superar reptes complicats i assolir metes que poden parèixer inabastables. En el meu cas particular, amb el transcurs dels anys, al fer vista enrere i analitzar la meua trajectòria personal i professional, he comprès que moltes de les idees de la meua joventut les he plasmat a poc a poc en la meua investigació, d'una manera lenta, però contínua, amb lògiques adaptacions, però sense renunciar als principis bàsics del treball i de l'entusiasme per allò que un fa. Però, per a avançar, també hem de ser crítics... Amb el sistema, amb els resultats de la nostra investigació, amb els altres i amb nosaltres mateixos. No hem d'acceptar imposicions quan tenim el ferm convenciment que no són necessàries.

Els qui tenim el privilegi de dedicar la nostra vida a la investigació, hem de ser exemple de constància, però també d'una certa rebel.lia, especialment en moments difícils com els que vivim a hores d'ara, en els quals les retalla- 
des a la investigació són insofribles i extremadament perilloses per al nostre futur i el de les generacions futures. Lamentablement, els investigadors i les investigadores ens enfrontem no només a fortes retallades en els pressupostos, sinó també a sistemes de control moltes vegades absurds i ineficaços, que consumeixen massa esforços, massa energia, que hauria de dedicar-se a aspectes estrictament científics. Sistemes basats en la desconfiança, en els quals solen valorar-se poc els resultats finals de la nostra investigació, sinó més aviat els aspectes purament burocràtics. És una situació que, en el dia a dia, pot arribar a fer-se insuportable. Seria altament desitjable comptar amb sistemes organitzatius i de control basats principalment en els resultats finals i en els objectius a aconseguir, més que en les rutines burocràtiques. Però, malgrat tots els inconvenients, estic convençut que, fins i tot en aquests moments complicats, és possible una eixida. El caràcter interdisciplinari i transnacional de la investigació ens obliga a dirigir els nostres esforços i idees més enllà de les nostres fronteres. Hem de buscar la col.laboració allà on siga necessari i no tancar-nos entre aquestes parets. Hem de ser imaginatius! Amb un treball seriós i esforçat, es poden aconseguir resultats notables. Perquè I'honestedat i el treball ben fet acaben sent reconeguts, més tard o més d'hora. Ara bé, és important reconèixer que els resultats tarden a arribar. Perquè només l'èxit tranquil, sense escarafalls, sense atalls, basat en fets contrastats i prou madurats, constitueix el verdader èxit, i és la base del reconeixement extern.

Però, per molt d'interès que posem en el nostre treball, només podrem avançar colllectivament si hi ha un compromís, una aposta decidida i valenta per la investigació. Els químics analítics tenim els mitjans i la capacitat de revelar les amenaces ambientals, els riscos alimentaris o l'avanç d'aquest flagell que és el consum de drogues de disseny, i per això tenim també la responsabilitat de dirigir les nostres investigacions cap aquests àmbits, tal com ens demanda la societat. He citat alguns exemples, però es podrien mencionar molts més sobre el paper fonamental de la QA, en proporcionar les dades necessàries per a detectar un problema de tipus ambiental, de seguretat alimentària, o toxicològic. Dades moltes vegades preocupants, però necessàries, les quals han estat la base de canvis legislatius posteriors.

Només amb un treball continuat i esforçat, amb investigacions allunyades dels vaivens polítics o de les modes, podrem aconseguir les metes que ens proposem. Tinc la ferma convicció que, d'aquesta manera, contribuirem a millorar la nostra qualitat de vida i a fer un món millor, més saludable i 
equilibrat, i el més important, ajudarem a conservar un planeta habitable, amb un futur esperançador per als nostres descendents.

Moltes gràcies,

Castelló de la Plana, 16 de setembre de 2013 


\section{BIBLIOGRAFIA}

Bijlsma L, Emke E, Hernández F, de Voogt P (2012), Investigation of drugs of abuse and relevant metabolites in Dutch sewage wàter by líquid chromatography coupled to high resolution mass spectrometry, Chemosphere 8: 1399-1406

Buchberger WW (2011), Current approaches to trace analysis of pharmaceuticals and personal care products in the environment, J Chromatogr A 1218: 603-618

Capriotti AL, Caruso G, Cavaliere C, Foglia P, Samperi R, Lagana A (2012), Multiclass mycotoxin analysis in food, environmental and biological matrices with chromatography/mass spectrometry, Mass Spectrom Reviews 31: 466-503

Carson R (1962), Silent Spring, Houghton Mifflin

Castiglioni S, Zuccato E, Fanelli R, eds (2011), Illicit drugs in the environment: occurrence, analysis and fate using mass spectrometry, $346 \mathrm{pp}$, John Wiley \& Sons, ISBN 978-0-470-52954-6

Cervera MI, Medina C, Portolés T, Pitarch E, Beltrán J, Serrahima E, Pineda L, Muñoz G, Centrich F, Hernández F (2010), Multi-residue determination of 130 multiclass pesticides in fruits and vegetables by gas chromatography coupled to triple quadrupole tandem mass spectrometry, Anal Bioanal Chem 397: 2873-2891

Colborn T, Meyers JP, Dumanoski D (1997), Nuestro futuro robado ¿Amenazan las sustancias químicas sintéticas nuestra fertilidad, inteligencia y supervivencia?, EcoEspaña, ISBN 9788492075874

Commission Regulation (EC) 1881/2006 setting maximum levels for certain contaminants in food

Council Directive 98/83/EC of 3 November 1998 on the quality of water intended for human consumption

Covaci A, Harrad S, Abdallah MAE, Ali N, Law RJ, Herzke D, de Wit CA (2011), Novel brominated flame retardants: A review of their analysis, environmental fate and behavior, Environ Int 37: 532-556

Daughton CG (2001), Illicit drugs in municipal sewage: proposed new nonintrusive tool to heighten public awareness of societal use of illicit/abused drugs and their potential for ecological consequence, in Pharmaceuticals and personal care products in the environment: scientific and regulatory 
issues, Daughton CG and Jones-Lepp T eds, Washington DC, American Chemical Society, Chapter 20, pp 348-364

Díaz R, Ibáñez M, Sancho JV, Hernández F (2012), Target and non-target screening strategies for organic contaminants, residues and illicit substances in food, environmental and human biological samples by UHPLC-QTOF-MS, Anal Methods 4: 196-209

Directive 2000/60/EC of the European Parliament and of the Council of 23 October 2000 establishing a framework for Community action in the field of water policy

Directive 2008/105/EC of the European Parliament and of the Council of 16 December 2008 on environmental quality standards in the field of water policy, amending and subsequently repealing Council Directives 82/176/ EEC, 83/513/EEC, 84/156/EEC, 84/491/EEC, 86/280/EEC and amending Directive 2000/60/EC of the European Parliament and of the Council European Commission Decision 2002/657/CE, Commission Decision of 12 August 2002 implementing Council Directive 96/23/EC concerning the performance of analytical methods and the interpretation of results European Monitoring Centre for Drugs and Drug Addiction (2008), EMCDDA Insights 9, Assessing illicit drugs in wastewater: potential and limitations of a new monitoring approach

Farrè M, Kantiani L, Petrovic M, Pérez S, Barceló D (2012), Achievements and future trends in the analysis of emerging organic contaminants in environmental samples by mass spectrometry and bioanalytical techniques, J. Chromatogr A 1259: 86-99

García Reyes JF, Hernando MD, Molina Díaz A, Fernández Alba AR (2007), Comprehensive screening of target, non-target and unknown pesticides in food by LC-TOF-MS, Trends Anal Chem 26: 828-841

Gracia-Lor E, Sancho JV, Serrano S, Hernández F (2012), Occurrence and removal of pharmaceuticals in wastewater treatment plants at the Spanish Mediterranean area of Valencia, Chemosphere 87: 453-462

Hernández F, Sancho JV, Ibáñez M, Guerrero C (2007), Antibiotic residue determination in environmental waters by LC-MS, Trends Anal Chem 26: 466-485 Hernández F, Sancho JV, Ibáñez M, Portolés T (2011a), Time of flight and Quadrupole time of flight mass spectrometry for identifying unknown contaminants and degradation products in the environment, "Encyclopedia of Analytical Chemistry», Robert A. Meyers (Ed), John Wiley: Chichester, DOI 9780470027318.a9233, Published December 15 (2011) 
Hernández F, Portolés T, Pitarch E, López FJ (2011b), Gas chromatography coupled to high-resolution time-of-flight mass spectrometry to analyze trace-level organic compounds in the environment, food safety and toxicology, Trends Anal Chem 30: 388-400

Hernández F, Sancho JV, Ibáñez M, Abad E, Portolés T, Mattioli L (2012), Current use of high resolution mass spectrometry in the environmental sciences, Anal Bioanal Chem 403: 1251-1264

Ibáñez M, Portolés T, Rubies A, Muñoz E, Pineda L, Serrahima E, Sancho JV, Centrich F, Hernández F (2012), The power of hyphenated chromatography/time of flight mass spectrometry in public health laboratories, J Agric Food Chem 60: 5311-5323

Ibáñez M, Bijlsma L, van Nuijs ALN, Sancho JV, Haro G, Covaci A, Hernández F (2013), Quadrupole-time-of-flight mass spectrometry screening for synthetic cannabinoids in herbal blends, J Mass Spectrom 48: 685-694

Kaufmann A (2012), The current role of high resolution mass spectrometry in food analysis, Anal Bioanal Chem 403: 1233-1249

Krauss M, Singer H, Hollender J (2010), LC-High resolution MS in environmental analysis: from target screening to the identification of unknowns, Anal Bioanal Chem 397: 943-951

Lebedev AT, ed (2012), Comprehensive Environmental Mass Spectrometry, ILM Publications, 510 pp, ISBN 978-1-906799-12-0

Mol HGJ, Zomer P, de Koning M (2012), Qualitative aspects and validation of a screening method for pesticides in vegetables and fruits based on liquid chromatography coupled to full scan high resolution (Orbitrap) mass spectrometry, Anal Bioanal Chem 403: 2891-2908

Peters RJB, Stolker AAM, Mol JGJ, Lommen A, Lyris E, Angelis Y, Vonaparti A, Stamou M, Georgakopoulos C, Nielen MWF (2010), Screening in veterinary drug analysis and sports doping control based on full-scan, accurate-mass spectrometry, Trends Anal Chem 29: 1250-1268

Picó Y, Barceló D (2008), The expanding role of LC-MS in analyzing metabolites and degradation products of food contaminants, Trends Anal Chem 27: 821-835

Portolés T, Pitarch E, López FJ, Hernández F (2007), Target and non-target screening or organic micropollutants in water by solid-phase microextraction combined with gas chromatography/high resolution time-of-flight mass spectrometry, Anal Chem 79: 9494-9504 
Regulation EC 396/2005 of the European Parliament and of the Council of 23 February 2005 on maximum residue levels of pesticides in or on food and feed of plant and animal origin and amending Council Directive 91/414/EEC

Richardson S (2012), Environmental mass spectrometry: emerging contaminants and current issues, Anal Chem 84: 747-778

Sanco Document/12495/2011, Method validation and quality control procedures for pesticide residues analysis in food and feed

Thomas KV, Bijlsma L, Castiglioni S, Covaci A, Emke E, Grabic R, Hernández F, Karolak S, Kasprzyk-Horden B, Lindberg LH, López de Alda M, Meierjohann A, Ort C, Picó Y, Quintana JB, Reid M, Rieckermann J, Terzic S, van Nuijs ALN, de Voogt P (2012), Comparing illicit drug use in 19 European cities through sewage analysis, Sci Total Environ 432: 432-439

Van Bavel B, Abad E (2008), Long-term worldwide QA/QC of dioxins and dioxinlike PCBs in environmental samples, Anal Chem 80: 3956-3964

Wang J (2009), Analysis of macrolide antibiotics using liquid chromatographymass spectrometry in food, biological and environmental matrices, Mass Spectrom Reviews 28: 50-92 


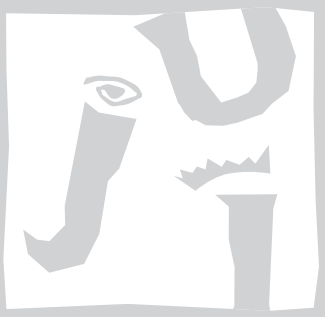

UNIVERSITAT JAUME•I 